\title{
Successful Ecological Regeneration of Opencast Coal Mine Spoils through Forestation: From Cradle to Grove
}

\author{
Martin Haigh ${ }^{1,2, *(1)}$, Patricia Woodruffe ${ }^{1}$, Margaret $D^{\prime}$ Aucourt ${ }^{1}$, Elanor Alun ${ }^{3}$, \\ Gillian Wilding ${ }^{1}$, Susan Fitzpatrick ${ }^{1}$, Ekaterina Filcheva ${ }^{4}$ and Maya Noustorova ${ }^{5}$ \\ 1 Cradle for Nature (NGO), cradlefornature.org, Witney OX29 8HT, UK; pmw.bentley@waitrose.com (P.W.); \\ kip.daucourt@gmail.com (M.D.); gillwilding@hotmail.com (G.W.); susan@fitzpatrick7.plus.com (S.F.) \\ 2 Department of Social Sciences, Oxford Brookes University, Oxford OX3 0BP, UK \\ 3 School of Architecture, Built and Natural Environments, University of Wales Trinity St David's, \\ Swansea SA1 8EW, UK; e.alun@uwtsd.ac.uk \\ 4 Institute of Soil Science, Agrotechnology and Plant Protection "N. Poushkarov-Sofia", 1080 Sofia, Bulgaria; \\ filcheva@itp.bg \\ 5 Department of Soil Science, University of Forestry, 1797 Sofia, Bulgaria; m.nustorowa@abv.bg \\ * Correspondence: mhaigh@brookes.ac.uk
}

Received: 15 April 2020; Accepted: 15 May 2020; Published: 20 May 2020

\begin{abstract}
The reclamation of surface (opencast) coal mines is not always successful; there remains a legacy of degraded land that burdens local communities. This article evaluates a community-oriented, low-cost means of geoecological regeneration, the "Cradle for Nature" strategy, which uses mosaic tree planting to foster positive natural ecological processes. Results show that, while the autocompaction of minestones quickly raises soil densities to levels hostile to plant growth, forestation helps moderate soil densities. Weathering concentrates metals in minestones, but 14 years of forestation reduced the loadings of five metals by $35-52 \%$. Twenty years of forestation doubled soil organic carbon to $>7 \%$; increased bacilli from $7 \%$ to $46 \%$; actinomycetes from $10 \%$ to $26 \%$; and soil microbe counts 12-15 times, especially in tree plantings treated with fertiliser. Soils under trees also supported a significantly greater earthworm biomass than under grass but, while open-canopy plantings had increased ground flora biodiversity, closed-canopy plantings had lower diversity and biomass. Following closure to grazing, ground biomass increased sevenfold. Young trees act as bird perches and significantly increase seed fall. Small mammal biomass and biodiversity increases after tree planting and higher predators appear. Varteg's constructed forest provides an effective "cradle" for an emergent geoecological system and its habitat mosaic maximises biodiversity.
\end{abstract}

Keywords: land reclamation; opencast/surface coal mining; ecological regeneration; South Wales Coalfield; Cradle for Nature

\section{Introduction}

Surface mining consumes land; land reclamation is the process of returning mined-through land to an environmentally and socially acceptable state. Unfortunately, as in the recycling of other industrial wastes, the recycling of surface-mined land can prove difficult. The reality of much land reclamation work falls far short of its initial promise and environmental reconstruction owes as much to faith as to science [1]. Even today, while land reclamation successes are showcased, its shortfalls and failures are ignored. Despite the routine assurances offered by those who propose new mines, the land left behind by surface coal mining tells its own story and it is clear that no one is able to guarantee its quality. All too often mining communities are left with a legacy of unreclaimed, poorly reclaimed, actively 
degrading, or otherwise substandard "reclaimed land". The fact is that, while the money generated by surface mining disappears quickly, its legacy remains for the very long term and often creates a burden for affected communities that, typically, they have neither the funding nor the technical resources to address.

This paper evaluates the long-term results of an attempt to design an effective low-cost, low-tech, community-based remedy for degraded and degrading "reclaimed" land and "orphan" surface mine spoil dumps. The approach is based on a strategy of selective tree planting to encourage the regeneration of more natural woodland and the restoration of soil fertility in land degraded by mining. Called the "Cradle for Nature" strategy [2], tree planting is used to reverse ongoing geoecological decline and to create a "Cradle for Nature", namely new habitats that can be colonised by local species, so fostering positive geoecological successional development. This contribution describes the ecological changes associated with tree planting on this project's test plots on the former opencast coal mine site at Varteg, South Wales, which is close to UNESCO's "Industrial Landscape World Heritage site" at Blaenavon. It evaluates current knowledge concerning the physical and chemical amelioration of soils, the development of soil microbial and earthworm ecology, changes in plant and animal ecology, and the role of birds in promoting seed fall and plant colonization.

\subsection{The "Cradle for Nature" Strategy}

Land reclamation projects reflect their designers' state of mind. If a reclamation begins to fail, usually this is because of the way the project was imagined and implemented as much as due to any natural process. Society decides both the timescales and the responsibilities of mining agencies and the balance struck between the miners' profits, the law, national needs, and the present or the future needs of society and/or the environment. It also decides the status of land reclamation and whether this is considered integral to mining or an (optional) "after thought" and whether it is conceived as a single action or an ongoing process.

Certainly, in today's legislative environments, it is becoming more difficult for miners to walk away from the aftermath of their mining, especially where the landscape includes so much. Those responsible for unreclaimed or poor quality "reclaimed" land, increasingly, are named, shamed, and used as evidence against their industry and in support of arguments against granting planning permits for further opencast mining, as finally realised, nationally, in Wales in 2018 [3-5]. Nevertheless, field inspection of past reclamation projects suggests the existence of three psychologies of opencast mine reclamation. First is "cosmetic" reclamation, which is designed only to pass legal inspection requirements at the end of a set period of aftercare. Second is economically sustainable reclamation, where the site is designed for a new economic use that can fund foreseeable future maintenance costs. Third is environmentally self-sustainable reclamation, where the land is restored to a condition where nature can take control and maintain the quality of the land, which is especially useful where no high value after uses are apparent. This style of reclamation, by restoring ecological functioning, allows natural processes to rebuild the land's environmental quality. This is the land reclamation of forestry, ecology, amenity, and green spaces and its key word is "self-sustaining", which is something only nature can provide [6]. Here, this project's "Cradle for Nature" strategy involves creating, through tree planting, "forest fallowing": new habitat conditions that foster the development of a natural ecosystem. The expectation is that, in time, this new ecosystem will supersede the artificial plantings that were needed, initially, to reverse previous environmental decline. The "Cradle for Nature" trees are planted as temporary biomass accumulators designed to improve local habitat conditions and nurture the development of the depleted geoecological system toward autonomous self-sustainability [2]. This paper describes the evidence to date that system restoration is beginning to take effect.

\subsection{Test Site Location and Description}

The Varteg test sites are located between 360 and 370 metres above mean sea level on the western outcrop of the South Wales Coalfield in Torfaen County Borough. The site is part of an artificial 
terrace created in 1963 during the reclamation of the Varteg Hill (Waun Hoscyn Extension) Opencast

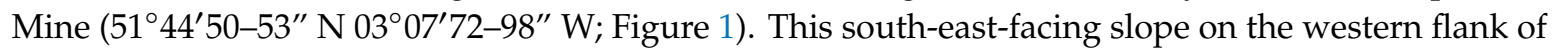
Cwm Afon Llywd is both relatively warm and exposed to the prevailing westerly winds. Its mean monthly air temperatures range from 2.5 to $15^{\circ} \mathrm{C}$. Its average rainfall (1971-2000) was $1543 \mathrm{~mm} /$ year. Evaporation is estimated as $472 \mathrm{~mm} /$ year on rough grazing land. Natural soils are at field capacity for 285-325 days/year but, commonly, there is a soil moisture deficit in July and August [7].

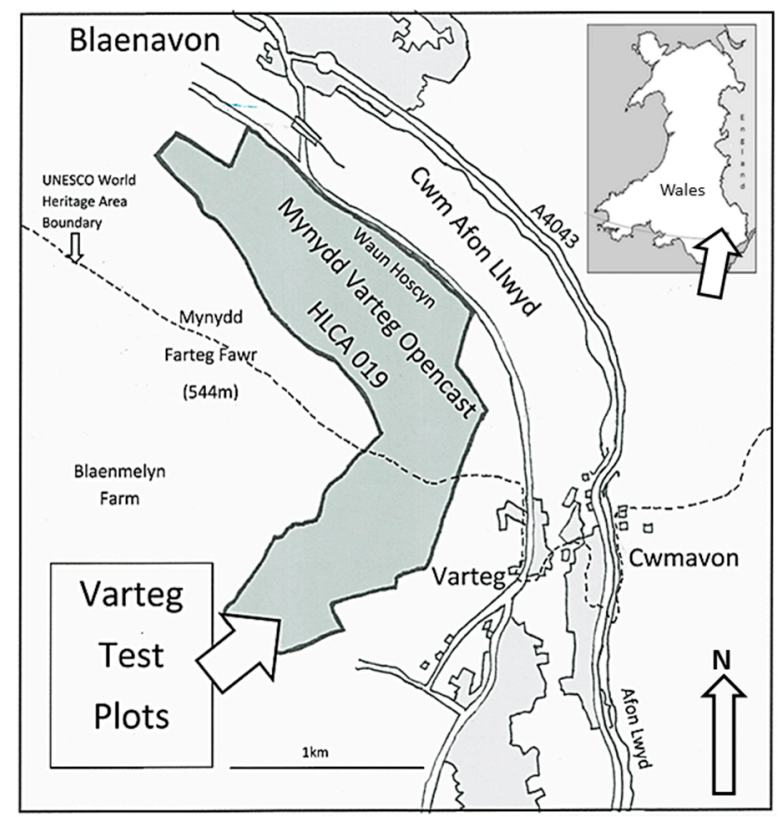

Figure 1. Location of Varteg test plots to the south of the UNESCO Blaenavon Industrial World Heritage area in South Wales.

The Varteg site lies a few km south of the "UNESCO Blaenavon Industrial Landscape World Heritage Site" and is on the southern edge of "HLCA 019 Mynydd Varteg Opencast" in the larger "Blaenavon Landscape of Outstanding Historic Interest", which is called "one of the best preserved, relict industrial landscapes in Wales" [8,9]. However, South Wales' long and now celebrated industrial history has left the coalfield area seriously deforested and, locally, mantled in coal mine and other spoils, some potentially contaminated (Figure 2).

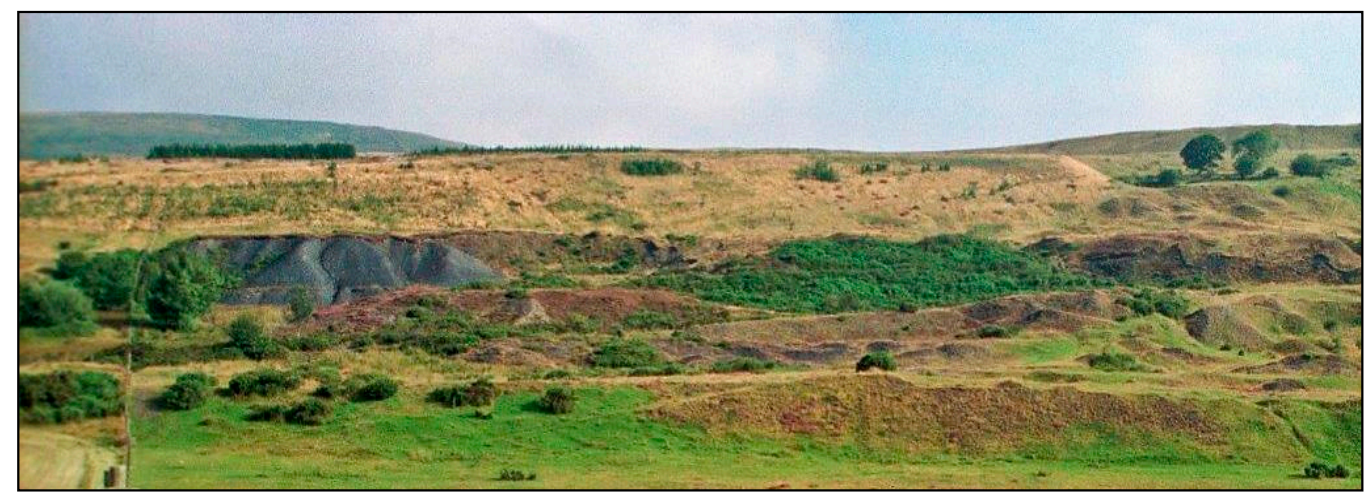

Figure 2. Unreclaimed land with early tree planting on the near horizon (1998).

\subsection{Method}

The method adopted for the biogeoecological restoration of the formerly "reclaimed" opencast coal land at Varteg is forestation. Since the mine spoils and even the thin layer of artificial topsoil 
remaining on this site are deficient in soil nutrients, exhibit poor soil structure and, below a $5 \mathrm{~cm}$ depth, lack organic matter, it was hoped that tree roots would improve soil structure and as bioaccumulators, improve soil qualities, especially the development of the soil microbial ecosystem [10,11]. Seven main tree species were used in mixed plantings for the forest reclamation. These were: 1 . common alder (Alnus glutinosa (L.) Gaertn) (although the nursery-supplied stock probably included some hybrids (A. $x$ hybrida), 2. oak supplied as Quercus petraea (Matt.) Liebl. (but including hybrids on the spectrum to Quercus robur L.), and 3. scots pine (Pinus sylvestris, L.), supplemented with smaller numbers of 4. silver birch (Betula pendula, Roth), 5. goat willow (Salix caprea, L.), 6. rowan (Sorbus aucuparia, L.), and 7. field maple (Acer campestre, L.). Each mixture was planted as a kind of ecological succession based on alder, a short-lived nitrogen fixer, and scots pine, as a second sheltering nursemaid species, finishing with oak as the legacy crop. The other four were added because of their tolerance of poor soil conditions, wet conditions and capacity to resist wind damage, respectively [12]. However, in accordance with the "Cradle for Nature" philosophy, these trees were planted in order to act as catalysts for natural succession [12,13]. Because of the low fertility and poor quality of the soils, a high-density planting strategy, 10,000 stems per hectare, was adopted in order to achieve a closed canopy quickly. Canopy closure on the more successful plantings was achieved approximately five years after planting.

Meanwhile, following the model of natural woodland regeneration, these plantings were designed to have a mix of fast-growing pioneer trees with shorter lifespans, such as alder, and slower growing trees with longer lifespans, such as oak. The idea was that the initial growth would be dense but that, over time, interspecific competition would thin out the planting and, on $>20$-year-old test plots, this process has clearly begun. Hence, the context for the soil and ecology results reported here is a mosaic of densely packed and shaded woodlands where the planting succeeded, an irregular scatter of small trees on the small number of test plots where it did not, plus either unplanted, grazed, grassland, or hawthorn scrub on sites that had been closed to grazing for more than 10 years but were not forested.

Plantings were undertaken from 1991 to 1997 (the larger area in Figure 3a), then again from 2003 to 2007 (the smaller area in Figure 3a,b). Each experimental series was set out as a Latin square of nine test plots [14], 3 by 3 matrices including three replications of three experimental variants applied to individual test plots of approximately 320 trees $[13,15,16]$. For example, three planting methods were evaluated on site. These were: "forestry-style" notch planting, where the ground is opened and a sapling, plus any admixtures such as compost, is heeled into the slot; "parks-and-gardens-style" pit planting, where the sapling is planted into a $30 \mathrm{~cm}$ diameter by $30 \mathrm{~cm}$ deep soil pit back-filled with spoil, compost, etc.; and "orchard-style" contour trench planting, where the sapling is notch-planted into a trench approximately $50 \mathrm{~cm}$ wide by $50 \mathrm{~cm}$ deep, which has been back-filled with the inverted soil profile plus supplements such as compost $[13,15]$. Ten-year survival for alder was $39 \%$ and oak $79 \%$, while more trench-planted trees survived than pit-planted or notch-planted trees [16]. Ten-year height for the better performing trench-planted woodland plots was $368 \mathrm{~cm}(\mathrm{SD}=124.84)$ for trees planted directly into the trench spoils and significantly more, $421 \mathrm{~cm}(\mathrm{SD}=137.78),(p<0.0005)$, for trees planted with 2 year slow release, NPK 15:9:9+3MgO, resin-coated fertiliser tablets [16]. Similarly, $\mathrm{DBH}$ (diameter at $1.3 \mathrm{~m}$ height) was $37.25 \mathrm{~mm}(\mathrm{SD}=19.87)$ for directly planted trees and slightly, but significantly, more on those planted with the slow release fertiliser tablets $(40.82 \mathrm{~mm}(\mathrm{SD}=18.71)$, $p=0.002)[16]$.

\subsection{Impact of Tree Planting on Ecology}

The following sections explore the broad findings concerning the ecological development of the soils, vegetation and wildlife on the Varteg Hill (Waun Hoscyn Extension) Opencast Mine test site, which was reclaimed, officially, in 1963. Its focus, however, is the impact of the forest plantation interventions (1991-2007) on ecological regeneration. Topics covered include the changes in soil physical and organic properties, especially soil bulk density, metal contaminant loadings, and soil microbial and earthworm populations. It also evaluates changes in both forest and ground flora, 
the role of birds in seed fall, and the development of small mammal populations both before and after forestation.

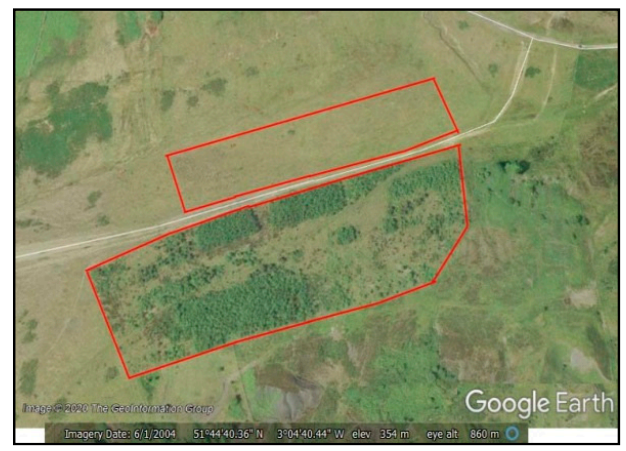

(a)

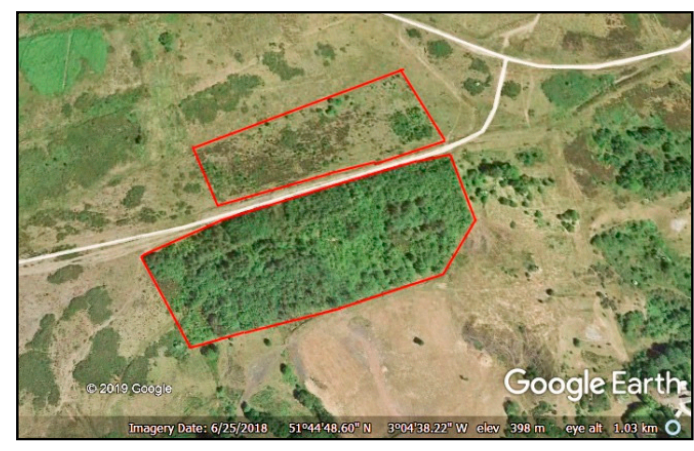

(b)

Figure 3. The Varteg test plots in (a) 2004 and (b) 2018.

\section{Soils}

\subsection{Soil Quality and Physical Characteristics}

Soils are a living resource that, treated properly, sustain and even improve their quality. Treated improperly, they suffer degradation, losing their fertility, structure, and water holding capacities. On reclaimed coal land, the focus is on assisting the self-creation of a new self-sustaining soil system. Frequently, this task involves helping a new soil profile and new soil ecosystem develop in and on the coal spoil discarded during mining as well as the mitigation of adverse soil properties such as compaction and chemical contamination [17].

On the Varteg, the soil profile consists of a thin, usually $5-8 \mathrm{~cm}$, organic layer overlying compacted, clayey, weathered mine spoils with abundant large cobbles of sandstone and coal shale. Below, at 50-70 cm depth, the weathered layer gives way to unweathered, clay-veneered minestone cobbles with bridged voids $[18,19]$. The soil $\mathrm{pH}$ is moderate at 5.7 near the soil surface but it declines with depth. Measured with a CP Instruments Antimony probe surface contact $\mathrm{pH}$ meter, the $\mathrm{pH}$ at the base of the topsoil (10-15 cm depth) is closer to 5.0 and in the weathered mine spoils ( $35-45 \mathrm{~cm}$ depth) it can fall to $4.0-3.6[20]$.

The key feature of surface coal mine spoils in South Wales is their instability. They include a large percentage of poorly consolidated shales and mudstones and, hence, a high proportion of water-unstable primary particles, which makes particle size analysis by the standard method of wet sieving meaningless. Weakly consolidated mudstones and shales, fractured by excavation, by subsequent pressure release, and by trafficking with heavy vehicles during reclamation [21], when exposed to wetting-drying and freeze-thaw processes for the first time, undergo rapid breakdown. In extreme cases, mudstone cobbles breakdown by slaking and dispersion within weeks of exposure, releasing a flood of fine constituent silts and clays into the soil. This is why, initially, bouldery mine spoils quickly become fine textured and compacted $[17,19]$. The released fine particles, if they do not wash off the surface, sink into the soil and become lodged in its pores, creating a dense impermeable layer in the soil profile. This quickly raises soil bulk density to high levels even though many harder shales, sandstones and ironstones survive for years.

\subsection{Soil Density}

Soil bulk density has been called the key indicator of land reclamation quality [22]. Here, soil bulk densities were measured by the small rings method [23]. This showed high soil bulk densities $\left(1.6-1.8 \mathrm{~g} \cdot \mathrm{cm}^{3}\right)$ in the weathered layer [17], despite the fact that these spoils include low-density coals $\left(\right.$ ca. $1.0 \mathrm{~g} \cdot \mathrm{cm}^{3}$ ), which reduce the bulk density scores. Dense, compacted layers make the soil more 
resistant to root growth and inhibit the movement of air and water; hence, they cause accelerated runoff and suffer vegetation dieback.

It has not been possible to track changes in soil bulk density on the Varteg site because of the number of replications required, the inaccuracies of the method and the stoniness of the weathered spoil. However, Varteg is the most southerly of a string of former opencast coal mines that excavated the same seams in the Blaenavon $\left(51^{\circ} 31^{\prime} \mathrm{N} 03^{\circ} 07^{\prime} \mathrm{W}\right)$ area. The principal among these are Pwll Du Opencast, reclaimed 1947-1948; Blaenant Opencast, reclaimed 1975-1977 with remedial work continuing until 1982; and Waun Hoscyn Opencast with its Varteg Opencast Extension, reclaimed in 1963, where the test sites are located. At the time of study, the Pwll Du reclamation was 50 years old, the Varteg reclamation 30-35 years old and the Blaenant reclamation 15-25 years old [17,19]. Table 1 compares data from these sites with the results from a recently back-filled planting trench on the Varteg site [20]. These data show that, left to itself, bulk density scores increase dramatically in the years after reclamation but also that, decades later, the effect begins to decrease. They also show how the organically enriched grass layer has far lower compaction records than less vegetated surfaces. Of course, the objective of this project is to use trees to expand this enriched and lower-density layer deep into the mine spoils.

Table 1. Changes of soil bulk density $\left(\mathrm{g} \cdot \mathrm{cm}^{3}\right)$ in a mine spoil chronosequence (N.b. ${ }^{*}$ and ${ }^{* *}$ refer to sample (n); n.a. means not available).

\begin{tabular}{ccccc}
\hline $\begin{array}{c}\text { Years Since } \\
\text { Disturbance }\end{array}$ & $<\mathbf{1}$ & $\mathbf{1 5 - 2 5}$ & $\mathbf{3 5}$ & $\mathbf{5 0}$ \\
\hline $\begin{array}{c}\text { Reclaimed } \\
\text { Opencast Site }\end{array}$ & $\begin{array}{c}\text { Varteg (New } \\
\text { Trench < 1 year) }\end{array}$ & $\begin{array}{c}\text { Blaenant } \\
\mathbf{( 1 9 7 4 - 1 9 8 2 )}\end{array}$ & Varteg (1963) & Pwll Du (1948) \\
\hline Depth 0-5 cm & n.a. & $1.35^{*}(0.21)$ & $1.41^{* *}(0.19)$ & $1.51^{*}(0.18)$ \\
Depth 5-10 cm & $1.41^{*}$ & $1.82^{*}(0.21)$ & $1.69^{*}(0.19)$ & $1.69^{*}(0.22)$ \\
Depth 10-20 cm & 0.81 & $1.81(0.20)$ & $1.73(0.30)$ & $1.75(0.18)$ \\
Depth 20-30 cm & 1.14 & $1.79(0.21)$ & $1.73(0.18)$ & $1.74(0.11)$ \\
Depth 30-40 cm & 1.48 & $1.82(0.22)$ & $1.79(0.19)$ & $1.79(0.19)$ \\
Depth 40-50 cm & 1.21 & $1.62^{* *}$ & $1.81^{* *}(0.19)$ & $1.81^{* *}(0.19)$ \\
Depth 50-60 cm & 1.61 & $1.81(0.22)$ & $1.76(0.19)$ & $1.76(0.19)$ \\
\hline Mean Bulk Density & 1.16 & $1.81(0.22)$ & $1.76(0.19)$ & $1.74(0.17)$ \\
$\left(\mathrm{g} \cdot \mathrm{cm}^{3}\right) 0-50 \mathrm{~cm}$ & $2\left({ }^{*} 1\right)$ & $42\left(21^{*}, 2^{* *}\right)$ & $22\left(11^{*}, 7^{* *}\right)$ & $58\left(* 26 ;{ }^{* *} 14\right)$ \\
\hline Sample $(n=)$ & & & & \\
\hline
\end{tabular}

Table 1 shows the great difference between soil bulk density in a newly created planting trench and that in less recently disturbed mine spoils. Spearman's rank correlation analysis shows that there is a significant positive correlation between the age of the site and soil bulk density at $0-5 \mathrm{~cm}(p<0.005$, $r=+0.39, n=68)$, and a weak negative correlation with depth at $5-10 \mathrm{~cm}(p=0.08, r=-0.25, n=54)$. Further, there are negative correlations between the age of the site and ground cover $(p<0.0005$, $r=-0.45, n=73)$ and between site age and soil $\mathrm{pH}$ at $0-5 \mathrm{~cm}(p<0.005, r=-0.71, n=30)$ and 25-30 cm depth $(p<0.005, r=-0.75, n=28)$. However, in Table 1 , the mean bulk density row highlights the initial sharp increase in bulk densities, which, despite subsequent amelioration, remain high even in the 50-year-old site. In summary, these areas of land became seriously compacted soon after reclamation and remained that way for many decades.

Similarly, soil density records collected by Humphrey in 1996 [24] from early 1993 trench plantings on the Varteg confirmed that soil bulk densities within the planting trenches were lower than elsewhere on site. They increase from 1.1 to $1.2 \mathrm{~g} \cdot \mathrm{cm}^{3}$ at the soil surface rising to approximately $1.5 \mathrm{~g} \cdot \mathrm{cm}^{3}$ at $30-45 \mathrm{~cm}$, and $1.6-1.7 \mathrm{~g} \cdot \mathrm{cm}^{3}$ in undisturbed mine spoils beneath the trench. Elsewhere on site, field measurements have linked the decreased soil density inside planting pits and trenches to increased soil moisture [13]. In combination, this helps explain the unusual behaviour of some large tree roots in these trenches, which preferentially track up and down the planting trenches and, occasionally, cross between trenches in the soil surface organic accumulation layer. 


\subsection{Soil Contamination (Metals)}

Metal contamination is not a problem typical of Wales' former surface coal mines, where the spoils are largely (90-95\%) derived from the "overburden" above the coal seam, mainly shales and sandstones. Nevertheless, opencast coal mine spoils often have metal loadings that border contamination thresholds. Of course, Atomic Absorption Spectrophotoscopy (AAS) analysis also shows that, commonly, deep-mine coal-spoils contain far higher loadings of metals and that, where an unusually large proportion of the exposed opencast spoils contain these materials, then local "hot spots" of severe contamination occur [25]. However, despite these circumstances, the general contribution of these lands to surface water contamination downstream in Cwm Afon Llwyd seems to be minimal. One reason may be that the development of the impermeable compacted layer in the soil (caused by accelerated minestone breakdown) allows the development of a very thin active layer in the soil and encourages rapid surface or near-surface runoff. Contact with more deeply buried minestones is restricted to percolation along occasional fissures [26]. Hence, while prolonged wetting of these minestones is linked to increased $\mathrm{pH}$ and metal loadings, repeated flushing of the surface soils dilutes any effect this may have off site. So, while ambient soil pH is close to $\mathrm{pH} 5.7$ (and surface waters may be as high as pH 6.8-7.3 (EC 237-277 $\mathrm{SS} / \mathrm{cm}$ ), local springs can be very acidic (pH 3.0). In February 2006, samples of surface runoff included elevated levels of arsenic $\left(<0.008 \mathrm{mg} \cdot \mathrm{L}^{-1}\right)$, iron $\left(\right.$ ca. $\left.0.2 \mathrm{mg} \cdot \mathrm{L}^{-1}\right)$, manganese $\left(0.015-0.064 \mathrm{mg} \cdot \mathrm{L}^{-1}\right)$, and nickel $\left.<0.008 \mathrm{mg} \cdot \mathrm{L}^{-1}\right)$ [27].

Just as natural weathering processes increase soil density and decrease stoniness [19], they also affect soil contamination. A comparison of unweathered and weathered minestones from two former surface coal mine sites a few km north of Varteg: Pwll Du (restored 1948) and Walters Group (restored 1994) was undertaken using Scanning Electron Microscopy (SEM) and Electron Probe Micro-Analysis (EPMA) [28]. These tests found that some metals exist as sulphides that may be oxidised to sulphates through microbial action. However, most are complexed with organic carbon and are not mobilised during weathering. These metals remain and the weathered residual becomes enriched. In this case, weathering enrichment carried $\mathrm{Cu}(145-675 \mathrm{mg} / \mathrm{kg})$ and $\mathrm{Zn}(96-485 \mathrm{mg} / \mathrm{kg})$ to join $\mathrm{Pb}(23.4-74.9 \mathrm{mg} / \mathrm{kg})$ above their soil contamination thresholds [28].

Of course, the impact of forestation is much greater. A comparative analysis of soil loadings of five key metals $(\mathrm{Zn}, \mathrm{Cd}, \mathrm{Mn}, \mathrm{Pb}$ and $\mathrm{Cu}$ ) in soil samples from those parts of the Varteg site that remained grassland and those from the control (i.e., unfertilised) plots of mixed species forest plantings of different ages, found that soil loadings decreased significantly and progressively through a 14 year forestation chronosequence [29]. After fourteen years, soil metal loadings had decreased by $52 \%$ for $\mathrm{Cd}$ (4.3 $\mathrm{mg} \cdot \mathrm{kg}^{-1}$ per year), $48 \%$ for Cu (2.1 $\mathrm{mg} \cdot \mathrm{kg}^{-1}$ per year), $47 \%$ for $\mathrm{Zn}\left(7.3 \mathrm{mg} \cdot \mathrm{kg}^{-1}\right.$ per year), $44 \%$ for $\mathrm{Pb}\left(7.1 \mathrm{mg} \cdot \mathrm{kg}^{-1}\right.$ per year) and $35 \%$ for $\mathrm{Mn}\left(45 \mathrm{mg} \cdot \mathrm{kg}^{-1}\right.$ per year). Studies of the metal loadings of leaves from common alder and silver birch found both to be involved in metal uptake, with birch taking up more $\mathrm{Cd}, \mathrm{Cu}, \mathrm{Zn}$ and $\mathrm{Mn}$ and alder taking up more $\mathrm{Pb}$. Leaf (but not soil) concentrations of $\mathrm{Zn}, \mathrm{Mn}$ and $\mathrm{Cd}$ (birch only) were significantly greater in older plantings. These results confirm that different tree species take up metals at different rates and also explain why mixed plantings might be more effective than monospecific in the forest phytoremediation of soils.

\subsection{Soil Organic Matter and Microorganisms}

Like soil density and heavy metal loading, soil organic matter content has been commended as a good indicator of soil quality [30], while measuring the state (size, composition and activity) of the soil microbial community has been suggested as a good way of assessing both soil degradation and the effectiveness of strategies designed to reverse it, not least in reclaimed coal lands [31]. Elsewhere, it has been shown that forestation has a major positive impact on initial soil-forming processes in mine spoils [32].

Soil samples (0-150 mm depth) were collected in 1998 and again in 2018 from the same Varteg test plots and analysed in the same soils laboratory in Sofia using the same standard methods. Preliminary results indicate that total organic carbon content in the surface $150 \mathrm{~mm}$ of soil has increased from 
$2.15-7.23 \%$ (1998) to $4.21-8.21 \%(2018)$ [33,34]. The total soluble fraction of humic and fulvic acids in 2018 ranged from $15 \%$ to $35 \%$ compared to $4 \%$ to $14 \%$ in 1998 [34]. In 1998, while humus formation remained at an initial stage, soil microbiological activity was greater under young trees, especially those given fertiliser, where the total microflora rose to $286 \times 10^{3} / \mathrm{g}$ (dry soil) with $\sim 85 \%$ being ammonifying bacteria [33]. In 2018, the population of microbes was 11.8 to 14.7 times higher than in 1998, while in sites where the trees were given additional fertiliser on planting, the microbial count was up 2.9 times compared with samples taken from control areas. In 1998, non-spore-forming bacteria dominated the microflora ( $85 \%$ ) but 20 years later, this had declined to $40 \%$; similarly, the proportion of micromycetes declined from $59 \%$ to $<19 \%$. Instead, in 2018, bacilli had increased to $46 \%$ (from $<7 \%$ ) and actinomycetes to $26 \%$ (from $<10 \%$ ) of the microbiocoenosis and were especially dominant in samples from sites where the trees had been planted with fertilisers [34]. The overall picture is that the soil microbial system is actively expanding and maturing with increased numbers of bacteria being involved in the breakdown of complex organic compounds and humification.

\subsection{Earthworms}

Past studies have shown that earthworms have a positive impact on soil structure, stability, bulk density, drainage, and more [35], which has led some to use earthworm inoculation as a soil restoration treatment $[36,37]$. However, at the start of the Varteg project, earthworms were a very infrequent sight; in fact, the first was not observed until 1995, following the digging of ca. 1000 planting pits and ca. $0.75 \mathrm{~km}$ of planting trenches. Since that time, however, earthworm sightings have become more common.

Studying earthworm populations is difficult due to seasonal variations, identification issues (not least its ethics [38], and imperfect methods of extraction. This study employed the non-toxic "hot" mustard extraction method, which has been shown to provide a consistent index of earthworm abundance across a range of soil and land use types [39]. This widely used standard technique is less destructive than hand sorting or methods involving more toxic chemicals. However, it impacts differently on different earthworm species as well as on different life cycle stages. Hence, while it may not provide a good indication of total biomass, it can show relative biomass differences [40]. Earthworms were sampled from 0.5 by $0.5 \mathrm{~m}$ square quadrats created as matched pairs, e.g., under pit-planted alder vs. under notch-planted alder. For sampling, first the surface turf was removed from the quadrat and hand sorted for earthworms; then the vermifuge ( $16 \mathrm{~g}$ of mustard powder per $2 \mathrm{l}$ of water) was applied to encourage the remaining earthworms to leave the soil. Four litres of the vermifuge were applied to each quadrat as quickly as the soil could absorb it. After a $10 \mathrm{~min}$ pause and the collection of exiting earthworms, the process was repeated.

Preliminary studies in 2010 compared results from single quadrats in four trench-planted plantations of different ages, one pit-planted area, and three control quadrats in unplanted areas (one in an ungrazed (fenced) area away from trees and two in grazed (unfenced) sites). Numbers and biomass of worms in all three control quadrats were very low. These 2010 studies discovered a significantly greater earthworm biomass ( $>35$ times greater) under 7-year-old alders than from neighbouring unmodified grassland (Table 2). Additionally, in the four trench-planted areas, there appeared to be a loose positive correlation between biomass of worms and age of plantation. The pit-planted area was unusual in having a low worm biomass but relatively large numbers of small worms; perhaps the smaller volume of broken-up spoil appealed less to the larger worms. However, results from the four trench-planted areas suggested that the biomass of worms increased as the plantation aged. Of course, as canopy closure is achieved, less leaf litter is removed by the wind and more accumulates at the soil surface, as this breaks down it provides both moisture and more food to support a larger population of earthworms. 
Table 2. Wilcoxon matched pairs comparison of earthworm biomass per quadrat in 2010.

\begin{tabular}{ccc}
\hline Comparison & Probability & Interpretation \\
\hline alder vs. open grassland & $<0.01$ & greater worm biomass under alder \\
under pit- vs. notch-planted alder & 0.02 & greater worm biomass under pit plantings \\
under trench- vs. notch-planted alder & 0.02 & greater worm biomass under trench plantings \\
under pit- vs. trench-planted alder & $\mathrm{ns}$ & ns: no significant difference \\
\hline
\end{tabular}

In 2011, a further study was carried out, but the new findings were inconclusive. However, it became apparent that earthworm distributions might differ inside and outside of the planting trenches and be affected by the different tree species planted, such as common alder, which fixes nitrogen, or scots pine, which can make the soil acidic. In addition, a number of different worm species were collected; some, like the lobworm or common earthworm (Lumbricus terrestris, L.), were large and thick bodied, while others were smaller and narrower; it was resolved to try and reduce this variability in subsequent sampling.

In 2012, eleven sets of three quadrats were collected from one trench-planted compartment. Each set consisted of (1) in-trench (under alder), (2) out-of-trench (under alder), and (3) control (in adjacent fenced area without trees) samples. The results (Table 3 ) showed that there were significantly more earthworms under trees, both in-trench and out-of-trench, than in the control samples. The biomass of these worms was significantly greater, and there were more large worms with a heavier biomass. More of the worms under trees were mature, and the overall mean weight of worms under the trees was greater than the controls (. In contrast, none of the comparisons of worm numbers and biomass between in-trench and out-of-trench samples reached significance (Table 3). Note that with 18 comparisons one "significant" result at $p=0.05$ should be expected by chance alone in this data set. However, the higher levels of significance observed and consistency of the results indicate that this is not a problem. Of course, the question remains open as to how much of this difference is due to the trees and how much to the loosening of the compacted mine spoil and/or the increased activity of the soil's microbiological system discussed earlier. Soil $\mathrm{pH}$ monitoring was carried out on these samples, which confirmed no significant differences in the soils tested. This suggests that soil $\mathrm{pH}$ is unlikely to be a cause of the differences in earthworm populations. Earthworm biomass is affected also by other factors; for example, in the 2012 data, under alder, there was a significant negative correlation between worm biomass and soil temperature $\left(r_{\rho}=-0.277, p=0.044\right)$. However, because no significant differences were found between the numbers or biomass of earthworms collected from in-trench and out-of-trench samples, it seems probable that the growth of the trees is key to the differences observed.

Table 3. Wilcoxon matched pairs comparison of earthworm data from 2012. (nb. IT means "Inside trench"; OT mean "Outside of trench (both under alder)"; C, control (open grassland); $N$ for tied pairs is reduced, ns means "not significant").

\begin{tabular}{cccc}
\hline Earthworms & IT vs. C & OT vs. C & IT vs. OT \\
\hline Total number & $T=10 N=11 p=0.05$ & $T=6 N=11 p<0.02$ & $T=10.5 \mathrm{~N}=11 \mathrm{~ns}$ \\
Total biomass & $T=2 N=11 p<0.005$ & $T=1 N=11 p<0.005$ & $T=22 N=11 \mathrm{~ns}$ \\
Number of large worms & $T=2 N=11 p<0.005$ & $T=0 N=7 p=0.02$ & $T=5 N=6 \mathrm{~ns}$ \\
Biomass of large worms & $T=2 N=11 p<0.005$ & $T=1 N=8 p<0.02$ & $T=30 N=11 \mathrm{~ns}$ \\
Number of mature worms & $T=5.5 N=10 p<0.05$ & $T=4 N=11 p<0.01$ & $T=9 N=9 \mathrm{~ns}$ \\
Mean weight of all worms & $T=0 N=11 p<0.001$ & $T=1 N=11 p<0.005$ & $T=19 N=11 \mathrm{~ns}$ \\
\hline Direction of difference & IT $>$ C & OT $>C$ & IT $=$ OT \\
\hline
\end{tabular}

Hence, these results demonstrate that forestation has made a significant positive difference to earthworm populations and, by extension, to enhanced soil fertility and rates of soil formation. Earthworm biomass is affected by tree planting, is greater under alder than grass, and increases over time. In 2010, earthworm biomass under 7-year-old alders was $>12.5$ times smaller than that under the 15-19-year-old alders studied in 2012. In 2012, the data also suggests strong positive correlations 
between earthworm biomass and both total tree cover $\left(r_{\rho}=0.573, p<0.0005\right)$ and the sum of the canopy diameters of the eight nearest neighbour trees $\left(r_{\rho}=0.450, p<0.008\right)$. In trench-planted and pit-planted areas, where there is a larger volume of loosened soil, earthworm biomass is $>3.5$ times greater than notch-planted areas [16]. However, in more mature plantations, the impact of the growing trees may be the most important influence on earthworm biomass.

The team was fortunate that, in all three years, the weather remained uniformly warm and dry during sampling. Had there been rain, the ground would have become softer and more damp, perhaps resulting in a better distribution of the vermifuge, but making it impossible to compare results from different situations. Earthworms tend to burrow deeper under unfavourable conditions; this might have led to a greater volume of worms near the surface if the ground were cool and damp with unpredictable consequences for these findings.

\section{Flora and Fauna}

\subsection{Vegetation and Ecological Succession}

Studies of the herbaceous flora of the Varteg test field and its immediate surrounds have been undertaken through approximately 20 years of the project. This has been undertaken to determine whether the tree-planting intervention had an impact on the ground flora and also whether or not it was associated with the spread of invasive species.

Vegetation was sampled by means of nested quadrats [41]. Several factors were considered, in particular, the project's timescale and ease of replication, given the role of volunteer workers. In practice, three concentric circles of 50, 100 and $200 \mathrm{~cm}$ in diameter were described using string attached to a central pin, which was, therefore, at the centre of each circle, unlike conventional square nested quadrats which share one corner as a common point. Plant species records were linked to these three sampling circles, whereby plants in the smallest circle scored 3, those in the second circle scored 2 and those in the outer circle scored 1; hence, a plant occurring in all three scored the maximum of 6 . Five replicate areas were tested in each plot, allowing an accumulative maximum score of 30 (Table 4).

Three sites were explored as follows:

Site A-Control (Grassland). This control site was situated adjacent to the project area in a location unaffected by either fencing or planting. Initially this area was well grazed by cattle, sheep, and rabbits. Although the sward was patchy, there were several constants including three grasses: Sheep's Fescue (Festuca ovina), Common Bent (Agrostis capillaris), and Mat-grass (Nardus stricta); whilst Woodrush species (Luzula sp.), Soft Rush (Juncus effusus) and Heath Rush (J. squarrosus) were also significant. Bare ground was minimal, but mosses were common, and lichens were also present. Of the various herbs noted, the composites were the most constant together with Heath Bedstraw (Galium saxatile). The sward fitted National Vegetation Classification (NVC) category U4 (Festuca ovina, Agrostis capillaris, Galium saxatile grassland) [42]—of which, there are many examples in the region on both relatively natural and disturbed industrial land $[43,44]$. At this time, the presence of gorse (Ulex sp.) was noted in the surrounding area but not considered to be of significance. Over the twenty year period, the presence of woody/scrub species has increased such that currently gorse, ling (Calluna vulgaris) and bilberry (Vaccinium myrtilis) all play a significant role in the composition of the sward, as can be seen by comparison of the vegetation to the west and north of the sites (Figures 2 and 3). The most likely reason for this change is the reduction in grazing pressure; it is possible that the site is now transitory between U4 and a heathland category such as H12 [45].

Site B-Successful Forest Plantation. The trees planted on this site, predominately oak and alder, thrived and therefore had a marked influence on the ground flora. When an area is made ready for tree planting, two major changes take place immediately; the area is fenced to exclude grazing animals and the soil is disturbed for (and during) planting. For a few years, the presence of the trees themselves may be a minor factor. However, even one year after planting, the change in plant species can be very marked (Table 4: Site B year 1). Many of the species typical of the U4 grassland have 
undergone a severe reduction in abundance; there is a total absence of lichens and mosses, while the amount of bare ground has climbed to $>60 \%$ (Table 4 : Site B year 1 and Site A year 1). Meanwhile, Sheep's Sorrel (Rumex acetosella) has become present in quantity along with the coarse grass Yorkshire Fog (Holcus lanatus) and Ribwort Plantain (Plantago lanceolata). Of course, these are mainly ruderal colonisers, plants typical of recently disturbed ground.

Table 4. Changes in flora after tree planting-a selection of species (nb. NDA: no data available).

\begin{tabular}{|c|c|c|c|c|c|c|c|}
\hline \multirow{3}{*}{ Species } & \multicolumn{3}{|c|}{ Site A } & \multicolumn{3}{|c|}{ Site B } & Site C \\
\hline & \multicolumn{3}{|c|}{$\begin{array}{l}\text { Unfenced, Grazed Grassland, } \\
\text { Undisturbed/No Tree Planting }\end{array}$} & \multicolumn{4}{|c|}{$\begin{array}{c}\text { Fenced, Ungrazed Forest Plantations } \\
\text { with Associated Disturbance }\end{array}$} \\
\hline & Year 1 & Year 14 & Year 21 & Year 1 & Year 14 & Year 21 & Year 14 \\
\hline \multicolumn{8}{|c|}{ Species characteristic of U4 grassland } \\
\hline Agrostis species & 29 & 20 & 26 & 30 & 27 & & 15 \\
\hline Anthoxanthum odoratum & & 12 & 17 & & 2 & & \\
\hline Festuca species & 29 & 27 & 27 & 21 & 8 & 6 & 8 \\
\hline Nardus stricta & 16 & 27 & 25 & 0 & 0 & 0 & 16 \\
\hline Galium saxatile & 23 & 26 & 12 & 6 & 8 & 6 & 8 \\
\hline Potentialla erecta & & 12 & 15 & & & & 22 \\
\hline \multicolumn{8}{|c|}{ Scrub species } \\
\hline Ulex species & & 6 & 16 & & & & 21 \\
\hline Calluna vulgaris & 3 & 3 & 14 & & & & 24 \\
\hline Vaccinium myrtilis & 4 & 22 & 17 & & & & 9 \\
\hline \multicolumn{8}{|c|}{ Woodland species excluding planted trees: } \\
\hline Hedera helix & & & & & & 24 & \\
\hline Crataegus monogyna & & & & 3 & & 12 & \\
\hline Quercus species & & 3 & & & & & 9 \\
\hline Betula pendula & & & & & & & 12 \\
\hline Alnus species & & & & & & 15 & \\
\hline Rubus fruticosus & & & & & 14 & 8 & \\
\hline Moss species & 29 & 30 & 27 & & 30 & 30 & 30 \\
\hline Lichen species & 18 & 14 & 15 & & & & \\
\hline Bare Ground & $0 \%$ & $0 \%$ & $<5 \%$ & $65 \%$ & NDA & $9 \%$ & $17 \%$ \\
\hline \multicolumn{8}{|c|}{ Totals of all species recorded during the surveys: } \\
\hline Grasses, rushes and sedges & 10 & 11 & 11 & 7 & 5 & 3 & 13 \\
\hline Herbs & 13 & 15 & 10 & 9 & 8 & 6 & 25 \\
\hline Woody species & 2 & 3 & 2 & 1 & 1 & 4 & 8 \\
\hline Total All Species & 25 & 29 & 23 & 17 & 14 & 13 & 46 \\
\hline
\end{tabular}

Fourteen years after planting, the flora on Site B had changed markedly. Species typical of a U4 grassland persisted along with several species that had colonised after the initial disturbance, such as Yorkshire Fog, Creeping Buttercup (Ranunculus repens), Selfheal (Prunella vulgaris), Strawberry (Fragaria vesca) and Bramble (Rubus fruticosus). More generally, species composition had changed to favour typical woodland species ahead of those of open grassland. Only ground-level moss cover remained similar in area to that found in unfenced grassland.

However, 21 years after planting (Site B year 21), woodland mosses covered much of the surface; only $9 \%$ remained as bare ground compared to $65 \%$ in year 1 . Notable in the 21 year record is the presence of young saplings of Hawthorn (Crataegus monogyna) and alder while Ivy (Hedera helix) was abundant on the woodland floor and also climbing into the canopy. Two species of fern had also become established: Broad Buckler Fern (Dryopteris dilatata) and Male Fern (D. filix-mas).

Site C-Younger and Less Successful Forest Plantation. While the initial condition of Site C, prior to planting, was very similar to that of Site A in year 1, it was planted much later than Site B and no data are yet available for year 21. For several reasons [16,18], Site C's trees did not establish well and, even by year 14, far more light reaches the ground than was the case for Site B. 
Here, despite the initial impacts of planting, the tendency has been for the original vegetation to regain its place in the sward with the adventive species typical of disturbance dying out. However, closure to grazing resulted in a greater sward height, which did not favour some of the diminutive herbs and grasses such as Early Hair-grass (Aira praecox). As has been the case, to some extent, outside the fenced areas after grazing was suspended, woody species such as ling, gorse and bilberry became much more abundant, so lending validity to the suggestion that grazing is an important factor in their suppression. During this time bare ground, once again, became minimal but the number of tree seedlings, derived either from seed of the planted trees or from others nearby, increased significantly. Seedlings of silver birch, alder, rowan and oak were all noted [16].

Table 4 provides a selection from the many species recorded on site. Those plants selected are indicative of the vegetation types encountered and serve to highlight the changes that have occurred. A precise species has not been identified in several instances, usually because more than one species is present on site and distinction is difficult. None of the woody species included in the table have been introduced as part of this project; tree species, such as alder and oak, were recorded as seedlings.

The most biodiverse plot is Site C. This was fenced prior to a relatively unsuccessful planting. The paucity of tree growth, absence of canopy closure, and lack of grazing have aided the establishment of a rich flora, particularly the herbaceous species. These, in turn, provide valuable sources of nectar as well as food plants for a range of insect species. By contrast, the closed tree canopy of Site B diminishes the ground flora and creates a more specialised habitat of young, secondary woodland (Figure 4).

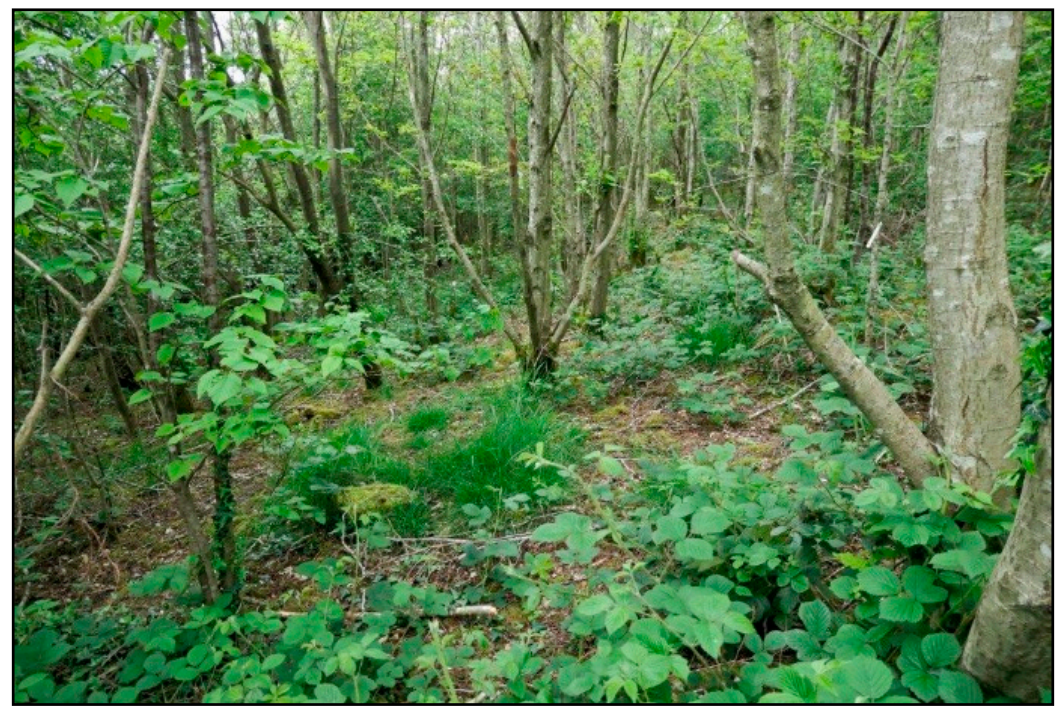

Figure 4. The woodland after 21 years.

\subsection{Volunteer Trees, Seed Rain and Bird Visitation}

As the planted trees began to grow and attract plants, insects and birds normally associated with a woodland ecosystem, the team began to consider ways of quantifying the impacts of these changes. Following the "Cradle for Nature" concept, the ways that "volunteer" rather than planted tree species arrived on site were key [2]. Introduction in the droppings of frugivorous birds seemed to be an important route. It seemed that, as tree cover in the area increased, more frugivorous birds were being attracted and were contributing a significant additional seed rain. As providing bird perches had been used successfully, in countries such as Australia and Indonesia, to restore pasture land to rainforest [46-51], it was decided to use the same method at Varteg to determine whether the provision of perches would also increase the seed rain in this Welsh upland environment. Anecdotally, the majority of the "volunteer" trees in the study area were either hawthorn or rowan-neither of which had been planted on the section of the site where the bird perches were to be set up, although both had been planted in a neighbouring field. 
The seed rain study ran from August 2014 to February 2016 and, for replicability, employed the methodology of Zweiner et al. [48]. Ten perches were constructed; each consisted of a single post with a two metre crossbar on top. This was dug into the ground and cemented in place (Figure 5). These perches were installed in an open area, away from the forest plantings, where there were very few trees $>1 \mathrm{~m}$ in height. The perches were then installed at co-ordinates determined by random number tables within the selected area, although placement often had to be adjusted slightly because of ground conditions; in some places the Varteg soil proved too hard to be opened by pickaxe and so a nearby location, with softer soils, had to be employed. Pilot studies and equipment testing in Varteg's challenging weather conditions were undertaken between August 2014 and June 2015. This work revealed a local drawback to using Zweiner's methodology exactly [48]. Principally, this was because the wind strength at Varteg made Zweiner's $2 \mathrm{~m}$ perches prohibitively tall, so perch height was reduced to $\sim 1.5 \mathrm{~m}$. Each perch was fitted with two seed traps, formed of plastic trays measuring $50 \times 80 \mathrm{~cm}$. These had four $5 \mathrm{~mm}$ holes each drilled into the base to allow water to drain away, and a $1 \mathrm{~mm}$ muslin mesh fitted on top.

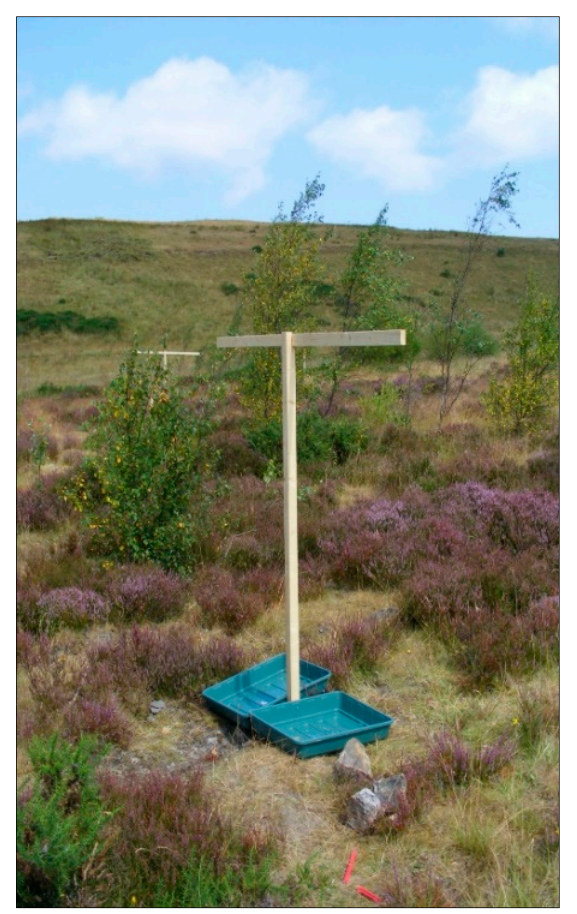

Figure 5. An example of a perch and seed trap (before the mesh was added).

Control plots were established in locations matched to the perches, i.e., if a perch was surrounded by gorse, so also would an equivalent control plot. The aim was to reduce site heterogeneity as a variable. Each control plot contained two seed traps, each held in place by a simple $254 \mathrm{~mm}$ stake.

During pilot studies, the data gathered recorded the presence or absence of birds at each plot using bird faeces as evidence. Seed rain data were gathered during the 2015/2016 fruiting season (July to February according to Snow and Snow [52]); the first rowan berries appear in mid-July, while the last hawthorn berries may appear as late as the following spring).

Independent sample t-testing revealed that the presence of perches had increased bird visitation very significantly $(p=0.00001$ ) compared to the control plots (Figure 6 's box and whisker plot reveals two data outliers, "18" and "19"). One simply records an unusually high number of samples collected in a single visit in June, while the other records, between April and June, regular visits by a bird that had adopted the control plot's $254 \mathrm{~mm}$ stake as a perch.) 


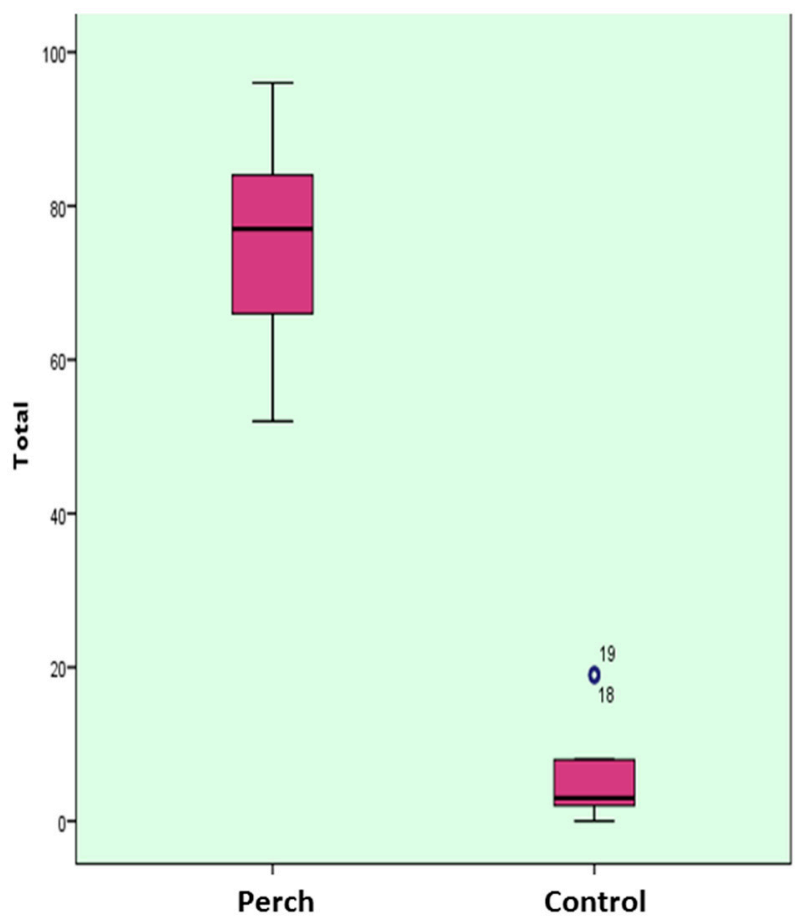

Figure 6. Total visitation numbers to perches and controls (Data outliers "18", "19": see paragraph above).

The local contexts of each plot were assessed to determine whether they influenced perch preferences. The number of trees $>1 \mathrm{~m}$ and the abundance of gorse and heather, both measured with a DAFOR scale, were recorded in a $5 \mathrm{~m}$ radius around each perch. Each step on the DAFOR scale was assigned a numeric value (i.e., "Dominant" $=5$, "Frequent" $=3$, "Rare" $=1$ ) and this value was combined with the number of trees counted to create "surrounding cover value". However, chi-square testing failed to establish any significant link between this score and perch visitations. Similarly, chi-square testing also found no significant evidence that particular perches received one bird species more than another.

Overall visitation numbers increased through time, with the highest activity recorded in the summer months (Figure 7). In total, there were 88 records of rowan seeds and 37 of hawthorn. From these, $78(89 \%)$ of the rowan seeds and $33(89 \%)$ of the hawthorn were under perches.

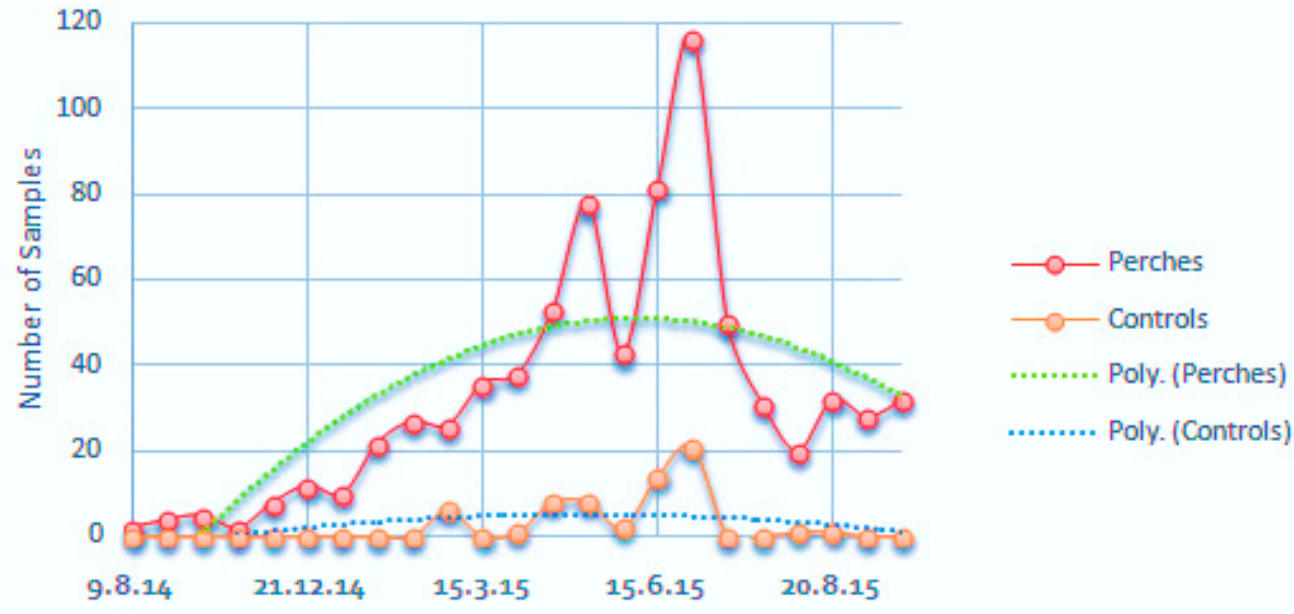

Figure 7. Bird visitation over time. 
The conclusion is that the provision of the perches accelerated seedfall by a factor of approximately 8 over a comparable area of open grassland. Independent samples t-testing confirms that seed rain was significantly higher under perches than in the control plots $(p=0.015)$, despite three outliers in the data (Figure 8). These findings also held for both rowan $(p=0.042)$ and hawthorn $(p=0.008)$ seeds individually.

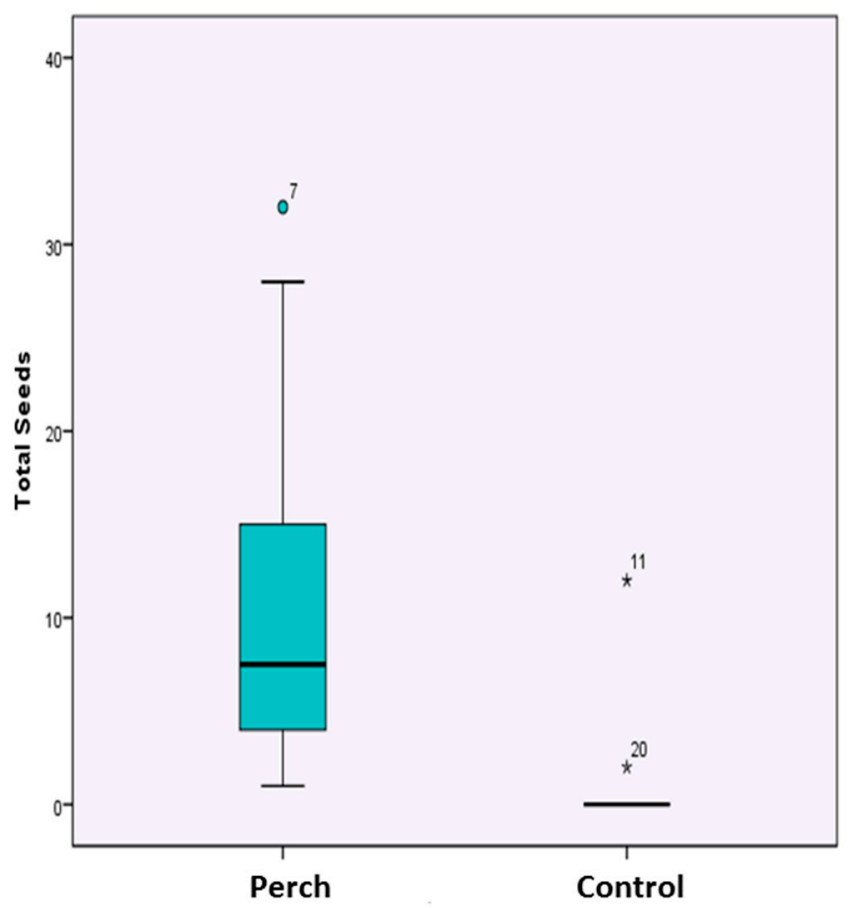

Figure 8. Total seed rain for perches and controls. (Data outliers “7”, “11”, “20”: see paragraph above).

Hence, providing perches for birds to use significantly increased the seed rain of rowan and hawthorn. This helps explain the presence of so many volunteers of these two species across the larger test area. The fact that far more rowan seeds were documented than hawthorn may be down to the time of year. More birds used the perches during the warmer summer months, which coincide with rowan's earlier fruiting season, while fewer birds used these exposed perches during stormy autumn/winter weather conditions. It is possible that avian biology is also a factor [52]; rowan berries and seeds are both, on average, smaller than hawthorn, and so, generally, taken in greater numbers by a bird in a single meal. This might be expected to cause rowan volunteers to be more numerous than hawthorn across the larger Varteg test area, but the opposite seems to be the case.

Perch visitation increased as the study progressed; it even continued at one perch during the month that the cross bar was broken. This suggests that, once the birds identified the presence of a perch, they returned loyally to the same perch. If this is true, it would seem likely that the young planted trees, and possibly also the posts of the fences used to close the land, provide natural perching opportunities for surrounding birdlife so increasing seed rain and probably, avian biodiversity.

\subsection{Self-Set Tree Species}

The aim of the "Cradle for Nature" project is the re-establishment of a self-sustaining geoecological system, which implies that the planted trees will ultimately be superseded by a self-generated forest. The harbingers of this new forest may be those tree species that have already self-set and become established in the current test plots. A major investment in the survey of these volunteer, i.e., self-set, tree species is planned. Meanwhile, a small survey of one of the less successful plantings, Cariad03, has been conducted, where the three different planting methods-notch planting, pit planting and trench planting-were trialled [16]. Here, relatively poor growth and high casualty rates among the 
planted trees had accelerated the arrival of volunteer trees. Just 10 years after forest planting, several of the larger trees onsite are volunteers with species evenly divided between goat willow, rowan and birch but not hawthorn, which dominates the areas outside the forestation test plots. Meanwhile, Cariad 03 volunteer trees have probably arrived from neighbouring test plots. To date, 41 trees, $7 \%$ of the trees alive in 2013, are self-set. Previous research suggests that ground preparation affects natural recruitment and that the relative percentage of native colonizing species was inversely correlated with the degree of disturbance [53]. Here, most of the self-set tree species have colonized vacated soil pits in the pit-planted areas (25/41) or less successfully established trench-planted (15/41) sections with a very few $(4 / 41)$ establishing in the notch-planted areas.

\subsection{Fauna}

Table 5 lists the two dozen or so species of mammal (excluding bats) that may either visit or live on site at Varteg. All of these species have either been recorded in the local area and/or are species that could be expected to occur in South Wales.

Table 5. Comparison of species of fauna recorded in South Wales with evidence found on the Varteg.

\begin{tabular}{|c|c|c|}
\hline Species & $\begin{array}{l}\text { Local Records } \\
\text { Exist/Expected to Occur in } \\
\text { South Wales }\end{array}$ & Evidence \\
\hline \multicolumn{3}{|c|}{ Insectivores } \\
\hline Hedgehog Erinaceus europaeus & [54-57] & incidental sighting of dead one [58] \\
\hline Mole Talpa europaea & [54-57] & $\begin{array}{l}\text { incidental sighting of half-eaten one under trees } \\
\text { [59] }\end{array}$ \\
\hline Common Shrew Sorex araneus & [55-57] & $\begin{array}{l}\text { in Longworth traps [58]; probable prints in track } \\
\text { tubes on the ground [59] }\end{array}$ \\
\hline Pygmy Shrew Sorex minutus & {$[55,56]$} & in Longworth traps [58] \\
\hline Water Shrew Neomys fodiens & $\begin{array}{l}\text { [55,56] Riparian, so } \\
\text { unlikely to be on site }\end{array}$ & \\
\hline \multicolumn{3}{|c|}{ Rodents } \\
\hline Grey Squirrel Sciurus carolinensis & {$[55-57]$} & $\begin{array}{l}\text { signs: nibbled pine cones, opened acorn shell and } \\
\text { oak debarking [60] }\end{array}$ \\
\hline Bank Vole Clethrionomys glareolus & {$[55,56]$} & $\begin{array}{l}\text { in Longworth traps [58]; possible droppings in } \\
\text { track tubes on the ground [60-62] }\end{array}$ \\
\hline Field Vole Microtus agrestis & [55-57] & $\begin{array}{l}\text { in Longworth traps [58]; live in open control area } \\
\text { [60]; signs of runs and holes along fencing [60] }\end{array}$ \\
\hline Water Vole Arvicola terrestris & $\begin{array}{l}\text { [56] Riparian, so unlikely } \\
\text { to be on site }\end{array}$ & \\
\hline Wood Mouse Apodemus sylvaticus & {$[55-57]$} & $\begin{array}{l}\text { in Longworth traps [58]; camera trap photos [59]; } \\
\text { prints in tubes and tunnel [59-61] } \\
\text { (Figures 9-11)/possible hair in hair tube [60], } \\
\text { possible droppings in track tubes on the ground } \\
\text { [60-62] }\end{array}$ \\
\hline House Mouse Mus musculus & $\begin{array}{c}{[55,56] \text { Associated with }} \\
\text { dwellings, so unlikely here }\end{array}$ & \\
\hline Brown Rat Rattus norvegicus & {$[55-57]$} & \\
\hline $\begin{array}{c}\text { Hazel Dormouse } \text { Muscardinus } \\
\text { avellanarius }\end{array}$ & $\begin{array}{l}\text { [55] Less likely, as } \\
\text { fragmented habitat }\end{array}$ & \\
\hline $\begin{array}{l}\text { Yellow-necked Mouse Apodemus } \\
\text { flavicollis }\end{array}$ & $\begin{array}{l}\text { [55] Less likely, as edge of } \\
\text { known range }\end{array}$ & \\
\hline
\end{tabular}


Table 5. Cont.

\begin{tabular}{|c|c|c|}
\hline Species & $\begin{array}{c}\text { Local Records } \\
\text { Exist/Expected to Occur in } \\
\text { South Wales }\end{array}$ & Evidence \\
\hline \multicolumn{3}{|c|}{ Carnivores } \\
\hline Red Fox Vulpes vulpes & [55-57] & $\begin{array}{l}\text { probable droppings near tubes on the ground } \\
\text { [60-62]; probable droppings on open ground near } \\
\text { white downy feathers [60-62]; possible predator } \\
\text { of the mole, corvid and the Guinea fowl [60] }\end{array}$ \\
\hline Pine Marten Martes martes & $\begin{array}{l}\text { [55] Less likely, as edge of } \\
\text { known range }\end{array}$ & \multirow{8}{*}{ blurred camera trap photo [59] } \\
\hline Stoat Mustela erminea & {$[55-57]$} & \\
\hline Weasel Mustela nivalis & {$[55-57]$} & \\
\hline Possible small mustelid & & \\
\hline Polecat Mustela putorius & {$[55,56]$} & \\
\hline Badger Meles meles & & \\
\hline Otter Lutra lutra & $\begin{array}{l}\text { unlikely to be on site (but } \\
\text { in Cwm Afon Llwyd and } \\
\text { local road-kill) }\end{array}$ & \\
\hline American Mink Mustela vison & $\begin{array}{l}\text { [55,56] Riparian, so } \\
\text { unlikely to be on site }\end{array}$ & \\
\hline \multicolumn{3}{|c|}{ Deer } \\
\hline Roe Capreolus capreolus & {$[55,57]$} & \\
\hline Fallow Dama dama & [55] & \\
\hline Reeves' Muntjac Muntiacus reevesi & {$[55]$} & \\
\hline \multicolumn{3}{|c|}{ Lagomorphs } \\
\hline $\begin{array}{l}\text { European Rabbit Oryctolagus } \\
\text { cuniculus }\end{array}$ & [55-57] & $\begin{array}{l}\text { probable fur and pieces of bone extracted from } \\
\text { bird pellets [60]; incidental droppings [60-62]; } \\
\text { incidental skeleton at base of tree [59] }\end{array}$ \\
\hline Brown Hare Lepus europaeus & [54-57] Local records & dead, hanging in a tree [60] \\
\hline \multicolumn{3}{|c|}{ Other animals } \\
\hline Blackbird Turdus merula & & camera trap photo [59] \\
\hline European robin Erithacus rubecula & & camera trap video of it on track tunnel roof [59] \\
\hline $\begin{array}{l}\text { Helmeted Guineafowl Numida } \\
\text { meleagris }\end{array}$ & Non-native & $\begin{array}{l}\text { incidental articulated wing in open area [60] } \\
\text { fairly whole, articulated leg on the ground under } \\
\text { the trees on same day [60] }\end{array}$ \\
\hline Corvid & & $\begin{array}{l}\text { incidental articulated black primary feathers on } \\
\text { the ground under the trees [60] }\end{array}$ \\
\hline Owl or bird of prey & & $\begin{array}{c}\text { fur balls under white-splashed post in mixed } \\
\text { tree/open area [60,62]; white downy feathers on } \\
\text { the open ground [60] }\end{array}$ \\
\hline Common Frog Rana temporaria & & in a Longworth trap [58] \\
\hline Common lizard Lacerta vivipara & & live in the open control area [58] \\
\hline Wasp & & old nest low in hawthorn [60] \\
\hline
\end{tabular}

Live trapping of small mammals was conducted on the site in late July 2002 and 2003 and early August 2004. The aim was to compare results from different habitats and how they changed over time. Each survey used 25 Longworth traps set out in a $20 \mathrm{~m} \times 20 \mathrm{~m}$ grid, according to the standard protocol [63]. One grid was set out in the plot planted in 1994, so 8-year-old trees in 2002, another in the plot planted in 1996, then 6 years old, and a control grid to represent conditions on the open hillside before the trees were planted.

The Longworth traps were supplied with hay bedding, hamster food, casters and sometimes with chopped apples. The casters or blowfly pupae were food for any insectivorous shrews and the apple was to provide some moisture. The traps were baited and set open during the afternoon sessions and again the following mornings, so potentially animals could be detained late afternoon and be processed the following morning; those captured late morning were processed late afternoon. Each survey consisted of six or seven sessions of trapping, processing and releasing.

In summer 2015 and 2016, a less intrusive method was used to detect small/medium mammals and other creatures. A footprint tunnel, originally designed to detect hedgehogs in gardens [64], and a 
camera trap (also known as a trail camera) were used together to help identify which animals leave which footprint tracks. The prism-shaped hedgehog tunnel contained bait in the centre, inked masking tape on either side, and sheets of paper outside those. The mammal then leaves inky footprints as it walks out of the tunnel over the paper. The camera was strapped to a nearby tree trunk or set on a tripod and pointed at one entrance of the tunnel (Figure 9). If an animal walked in the entrance, the movement was detected by the camera and a photograph was taken.

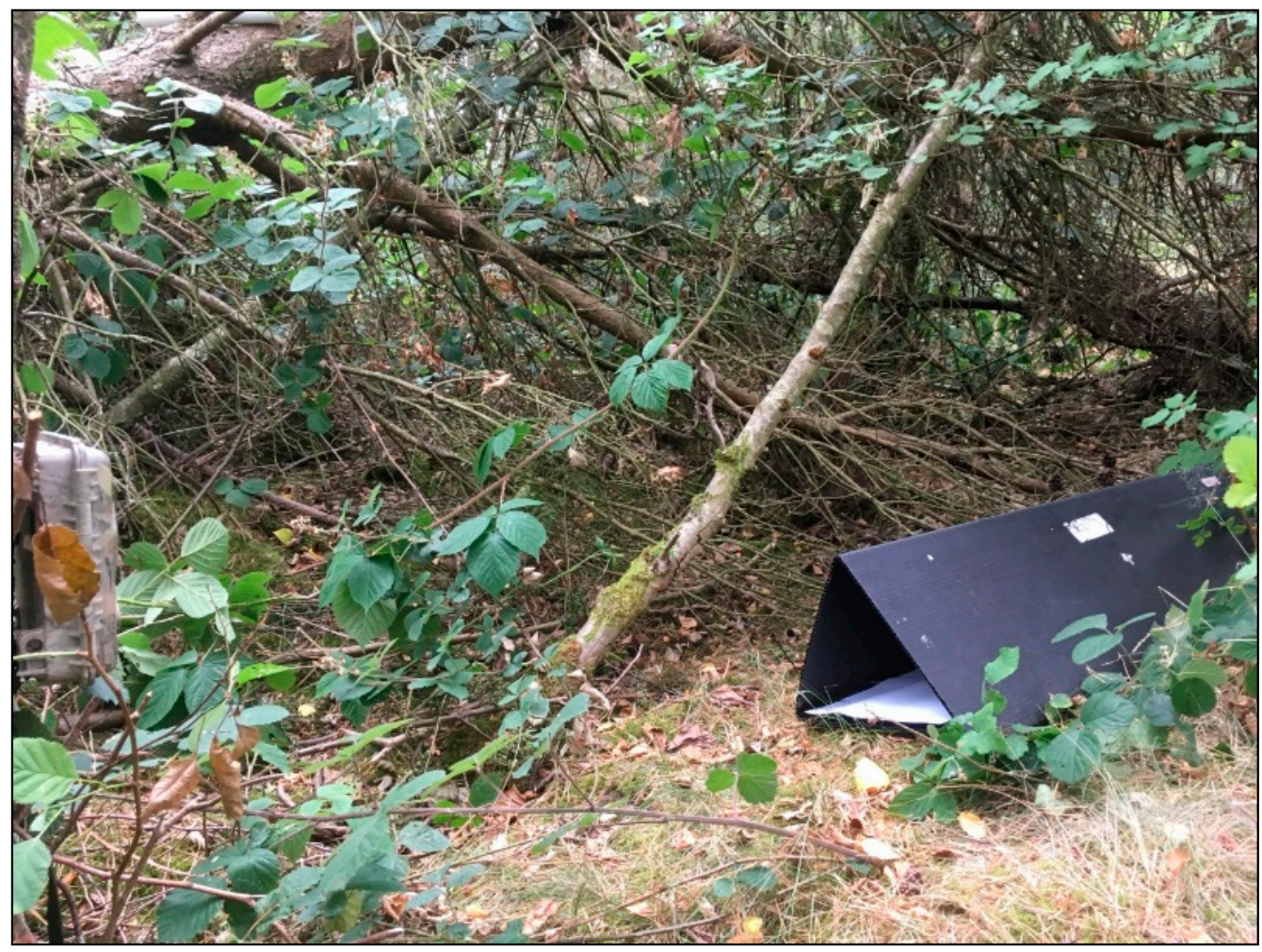

Figure 9. Camera trap and footprint tunnel.

In July 2018, a larger survey was conducted. A visual search for sightings and signs of animals was performed along one perimeter fence of the site, carefully looking for runs, homes, nests, snagged hairs, droppings and feeding signs [61]. At the same time, 13 footprint tunnels, 30 track tubes, 20 hair tubes and four camera traps were deployed in seven different plots of trees, ranging in planting time from 1992 to 2006. The tunnels and tubes were baited with a mixture of bird seed, peanuts, peanut butter, sliced hotdog sausages and dried mealworms.

The tunnels and half of the track tubes and half of the hair tubes were put on the ground near tree bases or along linear features or runs in the woodland and more open areas. (Figure 10a). The other tubes were secured onto branches in various plots. (Figure 10b). The camera traps were strapped to nearby trees to view four of the tunnels. The tunnels were to tempt in medium-sized mammals, e.g., hedgehogs, polecats, squirrels, as well as small ground animals, e.g., mice, and to record their footprints on the paper after they had investigated the bait.

The track tubes were an assortment of sizes and shapes and diameters of tube, including short sections of plastic drainpipe, flexible extractor-fan ducting, and standard dormouse nesting tubes consisting of a wooden base and end plus a square cross section corrugated plastic tube, with the addition of a white card and an inked card inside. These were fashioned for small mammals like shrews and mice (up to 25-35 mm diameter) and larger for other mammals. Similarly, the hair tubes were short sections of drainpipe or larger cylindrical items with a strip of double-sided sticky tape stuck to the roof of each tube, at right angles to the direction of travel of a creature [65,66]; Figure 10. 


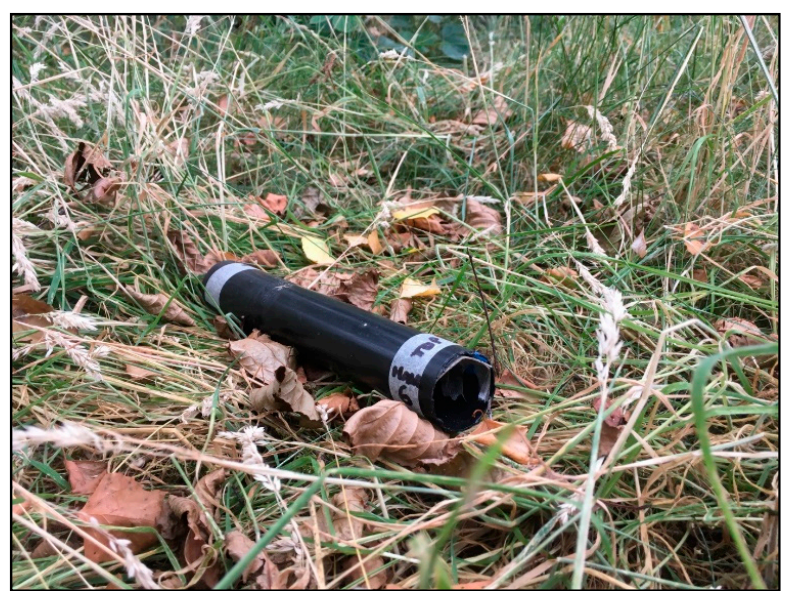

(a)

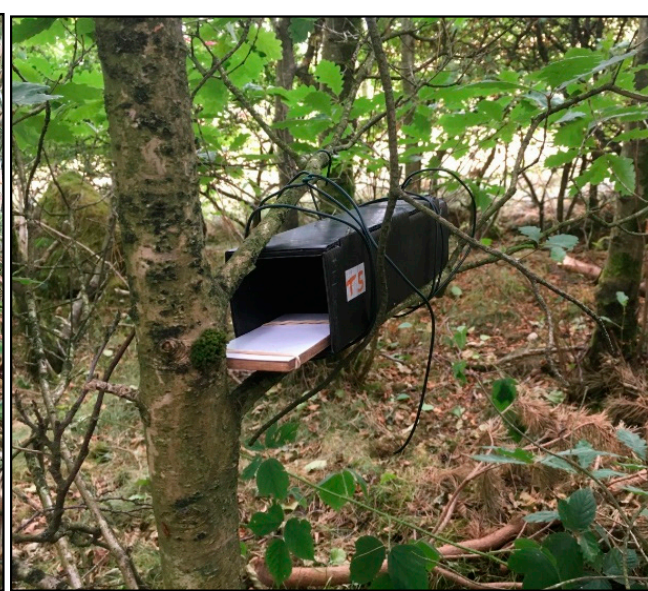

(b)

Figure 10. (a) Hair tube positioned on the ground; (b) Track tube attached to a tree branch.

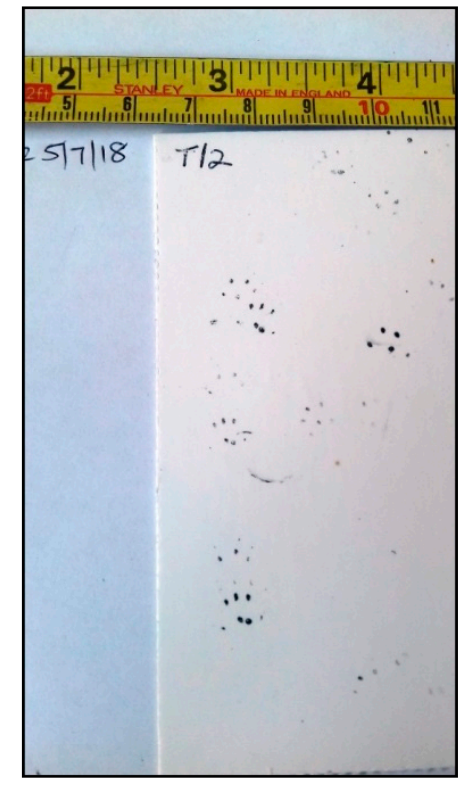

Figure 11. Prints of a wood mouse on a track card on a tree branch $[60,61,67]$.

As before, twice daily, i.e., morning and afternoon, all were checked and reset with bait as necessary, collecting used tracking cards from tubes, and paper with footprints from tunnels, any hairs stuck to sticky tape and the SD card from camera traps, recording where evidence was found. The list of mammals, and other animals for which evidence was found, is shown in Table 5.

From the early surveys that utilised Longworth traps, it is clear that the planting of trees encouraged some small mammals into the area. A small number of field voles and shrews were found in the open control area with most of the small mammals (bank voles, wood mice, common and pygmy shrews) occurring amongst the trees. In 2002 ten times more shrews than mice were captured, and the shrews were mostly in the older plot (then eight years old) which means there was insect food for the shrews. It might be that the field vole population declined, and the wood mouse population increased as tree cover increased over the years. The switch to track surveying rather than live trapping means that this change is not proven; however, evidence of hedgehog and mole implies that both earthworms and insect food was present. In addition, grey squirrels have moved in, feeding on the pine cones, while some evidence for larger mammals, a predator such as a fox, and also for a bird of prey has been found. 
Difficulties encountered with these mammal surveys limit the accuracy of the findings. More results would have been produced and better comparisons made if the use of Longworth traps had not been discontinued but concerns over animal welfare became paramount. Another limitation was that survey visits only lasted a maximum of five days, once a year, so there was little time for the animals to familiarize themselves with the survey equipment. Finally, it proved difficult to identify, precisely, which mammals were creating many of the tracks on inked card and hairs on sticky tape, while positioning the cameras to capture animal movement near the tunnels also proved hit and miss.

However, overall, as with results from the flora survey, tree canopy closure may have damped down any increase in animal biodiversity due to its associated reduction in ground vegetation and, consequently, insect biomass and diversity. Despite this, it is clear that the planting of trees has increased the diversity of species, the total population of mammals and fauna more generally, due to the increased biomass and greater variety of habitats than were available on the site prior to tree planting.

\section{Discussion}

The "Cradle for Nature" strategy [2], which these studies evaluate, is an attempt to reinstate a self-sustaining and self-improving geoecological system on land that is suffering degradation-in this case, because of the progressive failure of land reclaimed after surface coalmining [6]. In standard ecological theory, the restoration of a self-sustaining geoecological system on degraded land should result in a series of well-recognised changes in structure, composition and functioning. These changes are summarised on Table 6 along with evidence gleaned from the Varteg test plots.

Table 6. Progress in geoecological restoration; report card for the Varteg test plots.

\begin{tabular}{|c|c|c|c|}
\hline Attribute & $\begin{array}{l}\text { Degraded Land in } \\
\text { Theory }\end{array}$ & $\begin{array}{l}\text { Rehabilitated Land } \\
\text { in Theory }\end{array}$ & Evidence from the Varteg \\
\hline Biomass & Low & High & Increasing \\
\hline Carbon sequestration & Low & High & Increasing (0-15 cm depth) \\
\hline Soil depth & Decreasing & Increasing & Development of humus horizon \\
\hline Soil density & $\begin{array}{c}\text { Extreme } \\
\text { (usually high) }\end{array}$ & Equable & $\begin{array}{c}\text { Less extreme } \\
\left(>1.7 \text { down to }<1.5 \mathrm{~g} \cdot \mathrm{cm}^{3}\right)\end{array}$ \\
\hline Soil chemistry & Extreme & Equable & $\begin{array}{l}\text { Reduction in metal contaminant loadings } \\
\text { (by }>35 \% \text { over } 14 \text { years for } 5 \text { key metals) }\end{array}$ \\
\hline Soil biological activity & Low & Higher & $\begin{array}{l}\text { Increasing earthworm biomass and trees especially } \\
\text { under older trees; expanding microbial system, } \\
\text { with new emphasis on bacilli }\end{array}$ \\
\hline Hydrological state & More variable & More equable & $\begin{array}{l}\text { Improving-less surface runoff, more infiltration } \\
\text { and more soil moisture storage [16] }\end{array}$ \\
\hline Plant-available water & Low & Higher & $\begin{array}{l}\text { Improving due to increased organic matter in soil } \\
\text { and better soil structure }\end{array}$ \\
\hline Ecological structure & Simple & Complex & Transition from grassland to woodland \\
\hline $\begin{array}{c}\text { Undecomposed debris as } \\
\text { proportion of organic } \\
\text { matter }\end{array}$ & High & Low & $\begin{array}{l}\text { Very high initially, now lower due to increasing } \\
\text { activity and recycling in the soil ecological system }\end{array}$ \\
\hline Ecosystem niches & $\begin{array}{l}\text { Low number of } \\
\text { ecological niches }\end{array}$ & $\begin{array}{l}\text { High number of } \\
\text { ecological niches }\end{array}$ & $\begin{array}{l}\text { Number of ecological niches increased greatly } \\
\text { during the phased, annual planting, transition } \\
\text { from grassland to woodland and consequent } \\
\text { creation of habitat mosaic }\end{array}$ \\
\hline Biodiversity & Usually lower & Usually higher & $\begin{array}{c}\text { Increased due to the creation of the habitat mosaic } \\
\text { on site, but probably reducing as the site matures } \\
\text { to dense forest }\end{array}$ \\
\hline Life cycles & Short & Long & Grass to trees \\
\hline Population regulation & $\begin{array}{l}\text { Mainly by physical } \\
\text { environmental } \\
\text { factors-heat } \\
\text { drought, etc. }\end{array}$ & $\begin{array}{l}\text { More by biologically } \\
\text { mediated factors }\end{array}$ & $\begin{array}{l}\text { Forest microclimate ameliorates the impact of } \\
\text { physical environment, while deeper, more } \\
\text { organically enriched, soils buffer moisture change. } \\
\text { Forest mosaic increases opportunities for } \\
\text { interspecific competition }\end{array}$ \\
\hline
\end{tabular}

Inevitably, it has not proved possible to measure, let alone monitor, all aspects of the geoecological system and some of the evidence from the Varteg must be inferred. To date, major omissions include insect life, which is an important part of a developing food web, although casual observation indicates that the new woodlands support the larval stages of a host of insects and that the mosaic of woodland, scrub and open grassland created on site through the strategy of annual planting provides a much 
greater range of niches than the unplanted grassland. Similarly, data on the soil macro fauna are limited to earthworms and while preliminary studies of bryophyte succession have been undertaken on site, these results are not yet available.

Soil compaction and autocompaction through accelerated weathering have created a very hostile rooting environment in the substrates of most former opencast lands in Wales [68]. Soil densities below 10 or $15 \mathrm{~cm}$ often rise to levels close to or beyond the critical threshold for root penetration, often 1.6-1.8 $\mathrm{g} \cdot \mathrm{cm}^{3}$, where soil pore sizes are reduced to levels too small for root-hair penetration [17]. Of course, some root penetration still occurs along macro-pores and fissures. At Varteg, tree growth in loosened ground maintains lower soil densities and increased soil moisture content. In other contexts, this tends to drop sharply to $<10 \%$ in samples collected below $15-20 \mathrm{~cm}$, where soil density rises above $1.6 \mathrm{~g} \cdot \mathrm{cm}^{3}$ [68]. Forestation and soil loosening also improve the earthworm habitat and earthworm biomass, which in trench-planted and pit-planted areas was $>3.5$ times greater than in notch-planted areas [16]. In other plantations, the earthworm biomass of both within-trench and adjacent out-of-trench samples was far greater than in samples collected from unplanted grassed control areas (Table 3).

Despite some contamination hotspots [25], these opencast coal mine spoils have borderline levels of soil contamination and very low soil fertility. Natural weathering tends to enrich some of these metal contaminants, potentially raising contamination levels above recognised thresholds [28]. However, Desai's tests of a forestation chronosequence show that as trees grow, the loading of five soil metal contaminants declines very substantially, partly due to uptake into the tree's tissues and partly by mobilisation into leachate and runoff, where any potential harm is dissipated by dilution [26,29].

With improving soil structure and larger soil pores, there is a larger habitat for the soil biological system, which is also capable of creating more pore space and reducing soil density through its own activities, notably the burrowing of earthworms [36]. On the Varteg, studies in 2010 found $>35$ times greater earthworm biomass under 7-year-old alders than neighbouring unmodified grassland. However, the earthworm biomass under these young alders was $>12.5$ times smaller than that collected under adjacent alders in 13-19 years older trench-planted plots [16].

There were also positive changes in the size and activity of the soil microbiological system. Tests comparing soils sampled from the same sites in 1998 and 2018 showed that the 2018 population of microbes was 11.8 to 14.7 times higher than in 1998. Further, in sites where the trees were given additional fertilizer on planting, the microbial count was up 2.9 times compared with samples taken from control areas. In 1998, non-spore-forming bacteria dominated the microflora (85\%) but 20 years later had declined to $40 \%$, similarly the proportion of micromycetes declined from $59 \%$ to $<19 \%$. Instead, in 2018 , bacilli increased to $46 \%$ (from $<7 \%$ ) and actinomycetes $26 \%$ (from $<10 \%$ ) and were especially dominant in samples from sites where the trees had been planted with fertilizers [34]. Overall, the soil microbial system is active, increasing and maturing with increasing numbers of bacteria becoming involved in humification and the decomposition of organic materials [32,33]. During the processes of humification, two different scenarios are apparent: in test plots with organic fertilization, humic acids prevail over the fulvic acids, while in those receiving mineral fertilization, fulvic acids prevail over humic acids [33].

In general, records of the flora and fauna on site show similar trajectories. Whilst the diversity of micro and macrofauna within the soil has increased, the same cannot be said of the macroflora above ground. Results have shown the enormous changes which have taken place when trees are planted and develop, even over the short period of 20 years. A new and different habitat has been created including plants that are able to thrive in the shaded conditions under the tree canopy. However, survey results indicate that the most diverse flora is found where there is a mosaic of trees, scrub and open grassland. Here, the intention is to allow the trees to self-thin, as in natural woodland regeneration, and the selection of trees planted was designed with this in mind (Section 1.4). Recent records suggest that this process is underway and that high initial stocking density of 10,000 stems per hectare is slowly being 
reduced contributing, as the estimates of timber volume suggest, the considerable and continuing deposition of woody biomass on the woodland floor, thus hastening soil improvement.

Twenty years is a short time in the growth of a woodland, especially one planted piecemeal in harsh upland conditions [13,16-20,69]. However, the system of annual plantings has created an unusually complex habitat mosaic of fenced and unprotected grassy patches, forest test plots, and scrub, much of it dominated by self-set hawthorn. The complex ecosystem associated with mature woodland has yet to become established. However, elsewhere, mosaic and shrub-land habitats have proved best for increasing, at least, songbird diversity on reclaimed coal lands [70]. Here, results from mammal surveys suggest increases in diversity, numbers, and the length of food chains, while the bird seed fall work, which also suggests increasing populations and ecosystem productivity, demonstrates how forestation has significantly increased seed fall and so accelerated recolonisation of the site by local tree species. The team is conscious that much more work remains to be done. Thus far, the role of topographic position on soil and vegetation properties has not been explored, although preliminary results suggest that it has no significant impact on tree growth [71,72]. More work is also needed on insect and other invertebrate biomass but the expansion of small mammal populations in the woodland areas suggests that there is an ample food supply.

The State of Nature Report 2019 [73] shows that the rate of decline of the UK's biodiversity is yet to slow. Agricultural intensification continues, e.g., the area treated with pesticides increased by $53 \%$ between 1990 and 2010, and so has the growth of human population and its land-take. More land is required for amenity and recreation and also for wildlife. "Rewilding" more of the UK's vast areas of former coal land and similar brownfield sites could contribute greatly to providing more space for wildlife. In general, these low-quality and often unsightly lands have no economic use; they are unfit for either industrial/urban redevelopment or agriculture and, often, relatively distant from any modern release of pollutants, pesticides or fertilisers. In South Wales, the systematic rewilding of these lands could create extensive corridors of semi-natural vegetation, a reservoir for wildlife of national importance, and land of enhanced amenity and recreational value. Already, the National Botanic Garden of Wales has launched a project called "Grasslands for Life", which aims to monitor grasslands, including those on coal lands, by soil DNA barcoding. The results from Varteg, however, show that forestation is possible even for opencast coal land declared unfit for tree growth, which is why the Varteg was restored in 1963 as grassland. However, mosaic planting that mixes trees, grassland and scrub, which provides a relatively large array of eco-niches, seems to be a more effective way of promoting maximum biodiversity than reliance on any single land use.

\section{Conclusions}

This project aims to establish a self-sustaining geoecological system on former opencast coal mine-disturbed lands in the uplands of South Wales, which have become degraded since their "reclamation" in 1963. This is a common problem in the Heads of the Valleys region, which has been described as "a $100 \mathrm{~km}$ belt of ecological scar tissue" [6,74]. The solution proposed involves mosaic forestation with mixed woodland, not as an end in itself, but to provide a "Cradle for Nature", a place where a more natural geoecological system can develop and, in due time, take over and "rewild" the land [2]. Previous publications on this project have focused on the "construction of the cradle", i.e., the development of the planted trees and their impact on the soil $[13,15-20]$. This paper describes and summarises evidence collected to date on the "rewilding" process, the on-site colonization and development of natural organisms both in and above the soil and among and around the tree plantations.

Soil rehabilitation involves enhancing and integrating several hugely interlinked factors. These include soil depth, soil density and structure (so improving rainwater infiltration and percolation and the soil as a rooting medium), plant available soil moisture, humus and soil vitality $[75,76]$. Soil rehabilitation also involves the amelioration of soil toxicity, acidity and other negative chemical qualities [17]. Tests on the Varteg show, conclusively, that all of these factors are now showing signs of improvement. Data from neighbouring reclaimed opencast coal lands demonstrate how the accelerated 
breakdown of water-unstable minestones leads to soil autocompaction and raises soil densities to levels that deter root-hair penetration, water infiltration and plant available moisture; however, soil de-compaction for tree planting combined with tree growth helps keeps soil densities moderate [16]. Most former opencast coal lands have levels of metals that are slightly below the lower thresholds of contamination but also hot spots where contamination levels are exceeded. In addition, the weathering of minestones tends to concentrate metals. However, 14 years after forestation, contaminant loadings of five key metals $\mathrm{Cd}, \mathrm{Cu}, \mathrm{Zn}, \mathrm{PB}$ and $\mathrm{Mn}$ had decreased by $52 \%, 48 \%, 47 \%, 44 \%$ and 35\% respectively [15]. In addition, between 1997-2018, total soil organic carbon ( $<150 \mathrm{~mm}$ depth) increased more than by a factor of two or threefold to $>7 \%$ and soluble humic and fulvic acids from $4-14 \%$ to $15-35 \%$ [33,34]. The total soil microbial count increased by 11.8 to 14.7 times, especially under young trees treated with fertiliser and was three times greater than in grassed control areas [33,34]. In 2018, the population of microbes was 2.9 times greater than in samples from grassed control areas. In 1998, non-spore-forming bacteria dominated the microflora (85\%) but 20 years later, bacilli had increased to $46 \%$ (from $<7 \%$ ) and actinomycetes $26 \%$ (from $<10 \%$ ) and were especially dominant in sample from sites where the trees had been planted with fertilizers [34]. Since the discovery of the first earthworm in 1995, there has been a huge increase in earth worm biomass with that under 7-year-old alders $>35$ times greater in 2010 samples than in neighbouring unmodified grassland [77]. In 2012 samples, significantly, more earthworms, especially large mature earthworms, with significantly greater biomass were collected under trees than in the control samples (Table 3). This was true both for those areas disturbed for planting and those not disturbed. In combination, these results suggest that the Varteg soils have been greatly improved through the tree-planting intervention.

Studies of the herbaceous vegetation on the Varteg site show more mixed results. The most biodiverse are proved to be that of a relatively unsuccessful planting where, in combination, poor tree growth, an open canopy, and closure to grazing aided the establishment of a particularly diverse flora, which included self-set tree seedlings. Once grazing was halted, ground biomass increased sevenfold, woody species such as ling, gorse and bilberry became more abundant, and the original U4 (Festuca ovina, Agrostis capillaris, Galium saxatile grassland) [42] began to transition towards a type of heathland, perhaps H12 [45]. By contrast, the closed tree canopy of the more successful plantings diminished diversity and biomass of the ground flora. However, across the site as a whole, habitat diversity manifested by the mosaic of different tree plantations, self-set scrub, grazed and ungrazed grassland may have maximised on-site biodiversity.

Results from the small mammal surveys and bird work indicate that the planting of trees has also set the above ground ecosystem on a positive trajectory. The team has yet to collect data on soil invertebrates other than earthworms, or on insects, but the biomass and species diversity, their small mammal predators, mice and shrews, has increased and other larger mammals are moving in: hedgehog, mole, squirrel and higher predators including fox and raptors. The perch studies demonstrate that the young trees are providing new perching opportunities for birds, so increasing seed fall and, by extension, the regeneration of "volunteer" trees.

Of course, 20 years is a very short time in woodland ecosystem development, especially where there are infertile soils and hostile climatic conditions. Here, the full complex ecosystem associated with mature woodland is yet to emerge. However, the constructed forest, the "cradle" for the development of a new, autonomous, geoecological system [2], seems to be serving its role effectively. Meanwhile, the way that the Varteg test plots were created, using volunteers to plant usually 1000 or so trees each autumn, along with the spacing of each annual test plot, has created a complex habitat mosaic of trees of different ages, fence and unfenced (hence, grazed) grassland, and naturally regenerated scrub dominated by hawthorn. In combination, this has created a larger than usual array of econiches and so enhanced biodiversity. The team suggests that, at a landscape scale, a similar approach might do a great deal both to enhance the environmental quality of Wales coal mine-disturbed lands and to develop wildlife corridors and refuges that might help offset ongoing biodiversity decline [73]. 
Author Contributions: Conceptualization and methodology: M.H., E.A., M.D., P.W.; different aspects of validation, formal data collection, analysis and investigation: M.H., P.W., M.D., E.A., G.W., S.F., E.F. and M.N.; writing (first drafts): M.H., P.W., M.D., E.A. and E.F.; writing (review and editing) mainly G.W. assisted by M.H., P.W., M.D.; visualization: graphical abstract M.H., map, photographs and graphs: mainly G.W., E.A. and M.D. All authors have read and agreed to the published version of the manuscript.

Funding: This research received no external funding.

Acknowledgments: The team acknowledges the assistance of the $>400$ volunteers, many of whom came through Earthwatch (Europe) programmes and have contributed to the development of the Varteg site. We also send our sincere thanks to Frances Farrugia for her long-term fieldwork assistance and for her leadership of the earthworm surveys, to Katy Holvey, and to Mariana Hristova and Boika Malcheva for their laboratory work in Sofia, Bulgaria.

Conflicts of Interest: The authors declare no conflicts of interest.

\section{References}

1. Scherer, D. Evolution, human living and the practice of ecological restoration. Environ. Ethics 1997, 17, 359-379. [CrossRef]

2. Haigh, M. Chapter 32-Building a "Cradle for Nature": A paradigm for environmental reconstruction. In Bio-Geotechnologies for Mine Site Rehabilitation; Prasad, M.N.V., de Campos, P.J., Maiti, S.K., Eds.; Elsevier B.V.: Amsterdam, The Netherlands, 2018; pp. 593-616. [CrossRef]

3. Monbiot, G. Big Coal's Big Scam: Scar the Land for Profit and Let Others Pay; The Guardian: London, UK, 2015; p. 35 .

4. Milbourne, P.; Mason, K. Environmental injustice and post-colonial environmentalism: Opencast coal mining, landscape and place. Environ. Plan. Econ. Space 2017, 49, 29-46. [CrossRef]

5. Welsh Government of Wales. Planning Policy Wales, 10th ed.; Government of Wales: Cardiff, UK, 2018; pp. 98-99.

6. Haigh, M. The Aims of Land Reclamation. In Reclaimed Land: Erosion Control, Soils and Ecology (Land Reconstruct. Management); Haig, M., Ed.; A. A. Balkema (CRC Press): Rotterdam, The Netherlands, 2000; pp. 1-20.

7. Robinson, J. Agricultural Land Classification and physical characteristics and soil forming materials survey: Pwll Du Opencast Coal Site, Blaenavon, Gwent; ADAS Land Management Services: Cardiff, UK, 1989.

8. Torfaen County Borough. Blaenavon World Heritage Site Management Plan 2011-2016. 2011. Available online: https://www.visitblaenavon.co.uk/en/Publications/WorldHeritageSite/LookingAfterBlaenavon/ BlaenavonWHSDraftManagementPlan(2011).pdf (accessed on 16 May 2020).

9. Torfaen County Borough. Blaenavon Town Centre Conservation Area Appraisal and Management Plan 2017-2022. 2017. Available online: https:/www.torfaen.gov.uk/en/Related-Documents/Planning/ Conservation/Blaenavon-Town-Centre-Conservation-Area-Appraisal-and-Management-Plan-2017-2022. pdf (accessed on 16 May 2020).

10. Zipper, C.E.; Burger, J.A.; Skousen, J.G.; Angel, P.N.; Barton, C.D.; Davis, V.; Franklin, J.A. Restoring forests and associated ecosystem services on Appalachian coal surface mines. Environ. Manag. 2011, 47, 751-765. [CrossRef] [PubMed]

11. Zhao, Z.Q.; Shahrour, I.; Bai, Z.K.; Fan, W.X.; Feng, L.R.; Li, H.F. Soils development in opencast coal mine spoils reclaimed for 1-13 years in the West-Northern Loess Plateau of China. Eur. J. Soil Biol. 2013, 55, 40-46. [CrossRef]

12. Feng, Y.; Wang, J.; Bai, Z.; Reading, L. Effects of surface coal mining and land reclamation on soil properties: A review. Earth-Sci. Rev. 2019, 191, 12-25. [CrossRef]

13. Haigh, M.J.; Reed, H.; D'Aucourt, M.; Flege, A.; Cullis, M.; Davis, S.; Farrugia, F.; Gentcheva-Kostadinova, S.; Zheleva, E.; Hatton, E.; et al. Effects of initial fertilizer treatment on the 10-year growth of mixed woodland on compacted surface-coal-mine spoils, S. W. ales. Land Degrad. Dev. 2018, 29, 3456-3468. [CrossRef]

14. Zhang, H. Latin Square Design. In Encyclopedia of Research Design; Salkind, N.J., Ed.; SAGE: Thousand Oaks, CA, USA, 2010; pp. 99-704. [CrossRef]

15. Haigh, M.; Desai, M.; Cullis, M.; D'Aucourt, M.; Sansom, B.; Wilding, G.; Alun, E.; Garate, S.; Hatton, L.; Kilmartin, M.; et al. Composted municipal green waste enhances tree success in opencast coal-land reclamation in Wales. Air Soil Water Res. 2019, 12, 1-10. [CrossRef] 
16. Plamping, K.; Haigh, M.; Reed, H.; Woodruffe, P.; Fitzpatrick, S.; Farrugia, F.; D'Aucourt, M.; Flege, A.; Sawyer, S.; Panhuis, W.; et al. Effects of initial planting method on the performance of mixed plantings of alder and oak on compacted opencast coal-spoils, Wales: 10-year results. Int. J. Min. Reclam. Environ. 2017, 31, 286-300. [CrossRef]

17. Haigh, M.J. Soil Stewardship on reclaimed coal-lands. In Reclaimed Land: Erosion Control, Soils and Ecology; Haigh, M.J., Ed.; A. A. Balkema (CRC Press): Rotterdam, The Netherlands, 2000; pp. 165-274.

18. Haigh, M.; Reed, H.; Flege, A.; D’ Aucourt, M.; Plamping, K.; Cullis, M.; Woodruffe, P.; Sawyer, S.; Panhuis, W.; Wilding, G.; et al. Effect of planting method on the growth of Alnus glutinosa and Quercus petraea in compacted opencast coal-mine spoils, South Wales. Land Degrad. Dev. 2015, 26, 227-236. [CrossRef]

19. Haigh, M.J.; Sansom, B. Soil compaction, runoff and erosion on reclaimed coal-lands (UK). Internat. J. Surf. Min. Reclam. Environ. 1999, 13, 135-146. [CrossRef]

20. Haigh, M.J. Soil compaction on reclaimed surface coal-mine sites. J. Balk. Ecol. 1999, 2, 49-56.

21. Sweigard, R.J.; Escobar, E. A field investigation into the effectiveness of reclamation equipment alternatives in reducing subsoil compaction. Min. Sci. Technol. 1989, 8, 313-320. [CrossRef]

22. Ramsay, W.J. Bulk soil handling for quarry restoration. Soil Use Manag. 1986, 2, 30-39. [CrossRef]

23. Baize, D. (Ed.) Referentiel Pedologique; AFES/INRA: Paris, France, 1992.

24. Humphrey, M. An Investigation of the Impact of Soil Quality on Tree Growth on Land Reclaimed from Opencast Coal Mining at Varteg, South Wales. Master's Thesis, Birmingham City University (University of Central England), Birmingham, UK, 1997.

25. Desai, M. Phytoremediation: A Tool for Restoring Land Degraded due to Open Cast Coal Mining. Ph.D. Thesis, Oxford Brookes University, Oxford, UK, 2014. Available online: https://ethos.bl.uk/OrderDetails.do? uin=uk.bl.ethos.634790 (accessed on 16 May 2020).

26. Haigh, M.; Kilmartin, M.P. Illustrating the water quality impacts of reclaimed opencast coal lands, SE Wales. In Management of Municipal Watersheds in Mountain Regions; Proceedings of the 31st Session, Prague, Czech Republic, 4-6 September 2017; Palán, L., Křeček, J., Eds.; EFC/FAO Working Party on the Management of Mountain Watersheds, Food and Agriculture Organisation of the United Nations (FAO): Rome, Italy, 2017; pp. 87-115.

27. Smart, P.; Simpson, A. (Eds.) Varteg Coal Recovery and Reclamation Scheme, Blaenavon, South Wales, Hydrogeology and Contaminated Land Assessment, Final Interpretive Report; Faber-Maunsell AECOM: Birmingham, UK, 2006.

28. Dang, Z.; Liu, C.Q.; Haigh, M.J. Mobility of heavy metals associated with the natural weathering of coal mine spoils. Environ. Pollut. 2002, 118, 419-426. [CrossRef]

29. Desai, M.; Haigh, M.; Walkington, H. Phytoremediation: Metal decontamination of soils after the sequential forestation of former opencast coal land. Sci. Total Environ. 2019, 656, 670-680. [CrossRef]

30. MAFF. Towards Sustainable Agriculture: A Pilot Set of Indicators; Ministry of Agriculture, Fisheries and Food (MAFF), Her Majesty's Stationery Office: London, UK, 2000.

31. Harris, J. Measurements of the soil microbial community for estimating the success of restoration. Eur. J. Soil Sci. 2003, 4, 801-808. [CrossRef]

32. Filcheva, E.; Noustorova, M.; Gentcheva-Kostadinova, S.V.; Haigh, M.J. Impact of forestation on organic accumulation and microbial action in surface coal-mine spoils, Pernik, Bulgaria. Ecol. Eng. 2000, 15, 1-15. [CrossRef]

33. Filcheva, E.; Hristova, M.; Noustorova, M.; Malcheva, B.; Haigh, M. Soil Microbiological Activity and Organic Matter in Technosols of Wales; Institute of Soil Science, Agrotechnology and Plant Protection “N. Poushkarov"and University of Forestry: Sofia, Bulgaria, 2019; paper in preparation.

34. Noustorova, M.; Filcheva, E.; Gencheva, S.; Zheleva, E. Microbiological characteristics and composition of organic matter in materials from coal mining in Wales, United Kingdom. J. Balk. Ecol. 1999, 2, 57-61.

35. Scullion, J.; Malik, A. Earthworm activity affecting organic matter, aggregation and microbial activity in soils restored after opencast mining for coal. Soil Biol. Biochem. 2000, 32, 119-126. [CrossRef]

36. Butt, K.R. Inoculation of earthworms into reclaimed soils: The UK experience. Land Degrad. Dev. 1999, 10, 565-575. [CrossRef]

37. Butt, K.R. Earthworms in soil restoration: Lessons learned from United Kingdom case studies of land reclamation. Restor. Ecol. 2008, 16, 637-641. [CrossRef]

38. Drinkwater, E.; Robinson, E.J.; Hart, A.G. Keeping invertebrate research ethical in a landscape of shifting public opinion. Methods Ecol. Evol. 2019, 10, 1265-1273. [CrossRef] 
39. Lawrence, A.P.; Bowers, M.A. A test of the "hot"mustard extraction method of sampling earthworms. Soil Biol. Biochem. 2002, 34, 549-552. [CrossRef]

40. Bartlett, M.D.; Harris, J.A.; James, I.T.; Ritz, K. Inefficiency of mustard extraction technique for assessing size and structure of earthworm communities in UK pasture. Soil Biol. Biochem. 2006, 38, 2990-2992. [CrossRef]

41. Bonham, C.D. Measurements for Terrestrial Vegetation, 2nd ed.; Wiley-Blackwell: Chichester, UK, 2013; pp. 19-40.

42. Rodwell, J.S. British Plant Communities Volume 3: Grasslands and Montane Communities; Cambridge University Press: Cambridge, UK, 1998.

43. Evans, T. Flora of Monmouthshire; Chepstow Society; Chepstow Museum: Chepstow, UK, 2007; ISBN 0900278498.

44. ACW. Wye Valley Surveys. In Land Reclamation/Coal Recovery Scheme, Varteg Hill, Torfaen: Environmental Statement; Glamorgan Power for Torfaen County Borough Council: Cwmbran, UK, 2004.

45. Rodwell, J.S. British Plant Communities Volume 2: Heathlands and Mires; Cambridge University Press: Cambridge, UK, 1998.

46. Coulson, C.; Spooner, P.G.; Lunt, I.D.; Watson, S.J. From the matrix to roadsides and beyond: The role of isolated paddock trees as dispersal points for invasion. Divers. Distrib. 2014, 20, 137-148. [CrossRef]

47. Toh, I.; Gillespie, M.; Lamb, D. The role of isolated trees in facilitating tree seedling recruitment at a degraded sub-tropical rainforest site. Restor. Ecol. 1999, 7, 288-297. [CrossRef]

48. Zweiner, V.P.; Cardoso, F.C.G.; Padial, A.A.; Marques, M.C.M. Disentangling the effects of facilitation on restoration of the Atlantic Forest. Basic Appl. Ecol. 2014, 15, 34-41. [CrossRef]

49. Bustamante-Sánchez, M.A.; Armesto, J.J.; Landis, D. Seed limitation during early forest succession in a rural landscape on Chiloé Island, Chile: Implications for temperate forest restoration. J. Appl. Ecol. 2012, 49, 1103-1112. [CrossRef]

50. Graham, L.L.B.; Page, S.E. Artificial bird perches for the regeneration of degraded tropical peat swamp forest: A restoration tool with limited potential. Restor. Ecol. 2012, 20, 631-637. [CrossRef]

51. Heeleman, S.; Krug, C.B.; Esler, K.J.; Reisch, C.; Poschlod, P. Pioneers and perches: Promising restoration methods for degraded renosterveld habitats? Restor. Ecol. 2012, 20, 18-23. [CrossRef]

52. Snow, B.; Snow, D. Birds and Berries: A Study of an Ecological Interaction; T \& AD Poyser: London, UK, 1988.

53. Dement, W.T.; Hackworth, Z.J.; Lhotka, J.M.; Barton, C.D. Plantation development and colonization of woody species in response to post-mining spoil preparation methods. New For. 2020, 1-20. [CrossRef]

54. Glamorgan Power. Chapter12: Ecology. In Environmental Statement: Proposed Land Reclamation/Coal Recovery Scheme at Varteg Hill, Torfaen; Glamorgan Power for Torfaen County Borough Council: Cwmbran, UK, 2014.

55. Mathews, F.; Kubasiewicz, L.M.; Gurnell, J.; Harrower, C.A.; McDonald, R.A.; Shore, R.F. A Review of the Population and Conservation Status of British Mammals; 2018 A review of the population and conservation status of British mammals. (Natural England Joint Publication JP025, CEH Project no. C06029, C06940); Natural England: Peterborough, UK, 2018; Available online: http://nora.nerc.ac.uk/id/eprint/520584/ (accessed on 16 May 2020).

56. Poland Bowen, C. Mammals UK: An Introduction to the Nation's Wild Mammals; People's Trust for Endangered Species: London, UK, 2001.

57. Aderyn. Website Home; LERC Wales' Biodiversity Information and Reporting Database: Brecon, UK. Available online: https://aderyn.lercwales.org.uk/ (accessed on 25 March 2020).

58. D'Aucourt, M. Small Mammal Surveys.pdf. Available online: http://cradlefornature.org.uk/documents/ (accessed on 16 May 2020).

59. D'Aucourt, M. Survey using Hedgehog Tunnel and Trail Cameras on Varteg plots 2015 \& 2016. Available online: http://cradlefornature.org.uk/documents/ (accessed on 16 May 2020).

60. D'Aucourt, M. Report of Mammal Survey at Varteg in July 2018. Available online: http://cradlefornature.org. uk/documents/ (accessed on 16 May 2020).

61. Strachan, R. Mammal Detective; Whittet Books: London, UK, 1995.

62. Anon. What Animal Poo Is this? The Wildlife Trusts: Newark, UK; Available online: https://www.wildlifetrusts. org/wildlife/how-identify/identify-poo (accessed on 16 May 2020).

63. Gurnell, J.; Flowerdew, J.R. Live Trapping Small Mammals; A Practical Guide, 4th ed.; The Mammal Society: London, UK, 2019; Available online: https://www.mammal.org.uk/wp-content/uploads/2019/07/TrappingGuide-Additional-Information-2019.pdf (accessed on 16 May 2020). 
64. Thomas, E.; Wilson, E. Guidance-for-Detecting-Hedgehogs-Using-Tracking-Tunnels; People's Trust for Endangered Species: London, UK, 2019; Available online: https://ptes.org/wp-content/uploads/2015/06/Guidance-fordetecting-hedgehogs-using-tracking-tunnels.pdf (accessed on 16 May 2020).

65. Middleton-Burke, A. Feasibility of footprint tracking tubes to detect presence of the hazel dormouse. Mammal News 2017, 178, 1-2.

66. Cornally, A.; Lawton, C.A. Guide to the identification of Irish mammal hair. National Parks and Wildlife Service. In Irish Wildife Manuals; National Parks and Wildlife Service: Dublin, Ireland, 2016; p. 92.

67. Styles, H.T. A Guide to British Mammal Tracks and Signs; Wildlife World: London, UK, 2001.

68. Bending, N.A.D.; Moffat, A.J. Tree performance on minespoils in the South Wales coalfield. J. Appl. Ecol. 1999, 36, 784-797. [CrossRef]

69. Hale, K.; Spencer, M.; Peterken, G.F.; Mountford, E.P.; Bradshaw, R.H. Rapid carbon accumulation within an unmanaged, mixed, temperate woodland. Scand. J. For. Res. 2019, 34, 208-217. [CrossRef]

70. Margenau, E.L.; Wood, P.B.; Weakland, C.A.; Brown, D.J. Trade-offs relating to grassland and forest mine reclamation approaches in the central Appalachian region and implications for the songbird community. Avian Conserv. Ecol. 2019, 14. [CrossRef]

71. López-Marcos, D.; Turrión, M.B.; Martínez-Ruiz, C. Linking soil variability with plant community composition along a mine-slope topographic gradient: Implications for restoration. Ambio 2020, 49, 337-349. [CrossRef]

72. Alday, J.G.; Marrs, R.H.; Martínez-Ruiz, C. Soil and vegetation development during early succession on restored coal wastes: A six-year permanent plot study. Plant Soil 2012, 353, 305-320. [CrossRef]

73. Hayhow, D.B.; Eaton, M.A.; Stanbury, A.J.; Burns, F.; Kirby, W.B.; Bailey, N.; Beckmann, B.; Bedford, J.; Boersch-Supan, P.H.; Coomber, F.; et al. State of Nature 2019; National Biodiversity Network (State of Nature Partnership): Nottingham, UK, 2019; Available online: https:/nbn.org.uk/wp-content/uploads/2019/09/Stateof-Nature-2019-UK-full-report.pdf (accessed on 16 May 2020).

74. Walley, C. Carving out a Future; Rural Wales Magazine CPRW (Campaign for the Protection of Rural Wales): Welshpool, Powys, UK, 1994; pp. 22-24.

75. Flege, A. Recovering the Surface-Man-Made Soil at a Reclaimed Site in the South Wales Coalfield. Ph.D. Thesis, Department of Geography, McMicken College, University of Cincinnati, Cincinnati, OH, USA, 2003.

76. Shaxson, T.F. New Concepts and Approaches to Land Management in the Tropics with Emphasis on Steep Lands; Food and Agriculture Organization of the United Nations (FAO): Rome, Italy, 1999; Available online: http://www.fao.org/family-farming/detail/en/c/329766/ (accessed on 16 May 2020).

77. Frouz, J.; Pižl, V.; Tajovský, K. The effect of earthworms and other saprophagous macrofauna on soil microstructure in reclaimed and un-reclaimed post-mining sites in Central Europe. Eur. J. Soil Biol. 2007, 43, S184-S189. [CrossRef]

(C) 2020 by the authors. Licensee MDPI, Basel, Switzerland. This article is an open access article distributed under the terms and conditions of the Creative Commons Attribution (CC BY) license (http://creativecommons.org/licenses/by/4.0/). 